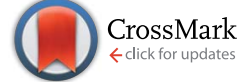

Cite this: Nat. Prod. Rep., 2014, 31, 1175

\title{
Natural products containing 'decalin' motif in microorganisms
}

\author{
Gang Li,† Souvik Kusari†* and Michael Spiteller*
}

Covering: up to February 2014

Microorganisms are well-known producers of a wide variety of bioactive compounds that are utilized not only for their primary metabolism but also for other purposes such as defense, detoxification, or communication with other micro- and macro-organisms. Natural products containing a 'decalin ring' occur often in microorganisms. They exhibit diverse and remarkable biological activities, including antifungal, antibacterial, anticancer and immunosuppressive activities, to name a few. This review surveys the natural decalin-type compounds that have been isolated from microorganisms, with emphasis on both chemical and biological implications. Total syntheses of some important decalin moiety-containing natural products are also highlighted.

www.rsc.org/npr

\section{Introduction}

Structural classification

Polyketide decalin

3.1 Monacolins

3.2 Monacolin derivatives

3.3 Side chains with a 3-oxopropanol or its derivative

3.4 Side chains with a pentanedienoic acid

3.5 Decalins with oxygenated diene/triene/tetraene side chains

3.6 Pyrone derivatives

3.7 Macrolides

3.8 Pyrrolidine-2-one

3.9 4-Hydroxy-2-pyridone alkaloids

3.10 Spirotetronates

3.11 Pyrrolizidines

3.12 Others

4 Isoprenoid decalin

5 Conclusions

6 Acknowledgements

7 References
The 'decalin' motif is found in an array of secondary metabolites produced by microorganisms, mainly fungi and actinomycetes. It is usually correlated with highly multifunctionalized or architecturally complex groups, thereby demonstrating surprising structural and functional diversity. Their intricate structures and diverse biological activities have attracted researchers around the world to investigate their biosynthesis, chemical synthesis, and the various facets of the functionalized decalin skeleton. ${ }^{\mathbf{1 - 3}}$

The decalin scaffold is primarily biosynthesized by microorganisms based on two biosynthetic derivations, isoprenoids (mevalonate) and polyketides (acetate). Isoprenoid-derived decalins typically belong to natural sesquiterpenoids and diterpenoids, and have been thoroughly covered in a series of reports by Fraga $^{4}$ and Hanson., ${ }^{5,6}$ However, there is a dearth of comprehensive reviews on polyketide decalin-derived secondary metabolites, either about their isolation and biological activities, or related syntheses. Furthermore, no critical observation about the differences or similarities of these decalin moiety-containing compounds from a microbial origin has been reported.

The polyketide decalin skeleton in some fungal or bacterial secondary metabolites is proposed to be biosynthesized by an enzymatic intramolecular Diels-Alder (IMDA) cycloaddition., However, only five potential or possible Diels-Alderase enzymes have been purified until now, ${ }^{7,8}$ of which lovastatin nonaketide synthase (LovB) and solanapyrone synthase (SPS) are proposed to be related to the decalin formation of lovastatin and solanapyrone A., ${ }^{9,10}$ It should be noted that the non-enzymatic catalytic synthesis of decalin in biological systems is also
Institute of Environmental Research (INFU), Department of Chemistry and Chemical Biology, Chair of Environmental Chemistry and Analytical Chemistry, TU Dortmund, Otto-Hahn-Str.6, 44221 Dortmund, Germany. E-mail: souvik.kusari@infu. tu-dortmund.de; m.spiteller@infu.tu-dortmund.de; Fax: +49-231-755-4084; +49-231755-4085; Tel: +49-231-755-4086; +49-231-755-4080

$\dagger$ These authors contributed equally to this work. 
possible, as suggested in a biomimetic total synthesis of the decalin compound $( \pm)$-UCS1025A. ${ }^{11}$ Based on the IMDA reaction of a substrate, ${ }^{9}$ all possible cyclization types to decalin are shown in Scheme 1. There are four comprehensive reviews on the syntheses of trans- or cis-decalins mainly in isoprenoids (mevalonate)-derived natural products., ${ }^{\mathbf{3 1 2}-14}$ However, to the best of our knowledge, reviews compiling different facets of the polyketide decalin have not been reported.

Therefore, given the present gaps in a comprehensive elaboration of the 'decalin' system and considering their intriguing structural and biological features, the target of this review is to provide an informative overview of the topic that can serve as a point of reference for an understanding of the functions and applications of decalin.

\section{Structural classification}

Decalin, as a ring system or scaffold, can be greatly modified by many functional groups, such as a side chain, or diverse moieties. The side chains are usually substituted by many functional groups such as hydroxyl, carboxyl, or $\mathrm{C}=\mathrm{C}$ and $\mathrm{C}=\mathrm{O}$

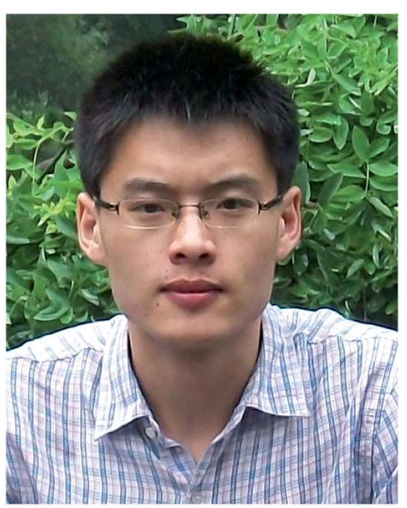

Gang Li received his B.Sc. degree (2009) at Shandong University of Traditional Chinese Medicine and M.Sc. degree (2012) under the supervision of Prof. HongXiang Lou from Shandong University, China. He is presently working at INFU, TU Dortmund, Germany for his doctorate with a fellowship from the China Scholarship Council (CSC). His research focuses on bioactive secondary metabolites from endophytic fungi.

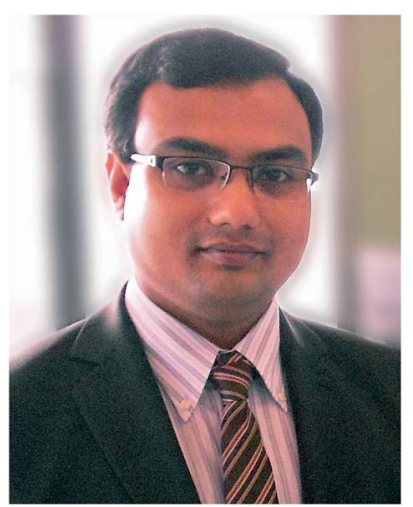

Souvik Kusari received bachelor and master degrees in Biotechnology from Bangalore University, India. He then earned a doctorate in Natural Sciences from INFU, TU Dortmund, Germany in 2010. After working as a scientist in the same institute for over two years, he became a visiting researcher at the Department of Plant Sciences, University of Oxford, UK for a year in 2013. He is also a visiting lecturer at the University of Yaoundé 1, Cameroon, Africa since 2012 within the scope of the DAAD "Welcome to Africa" initiative. His research interests include characterization of fungal and bacterial endophytes to evaluate their diversity, chemical ecology and biosynthetic pathways. double bonds. Many other moieties such as small lactone ring, pyrone, tetramic acid, unusual sugars, pyridone, tetronic acid, or pyrrolizidine act as diverse moieties, and are usually found in this type of compound. With the occurrence and interaction of these functional units in structures, a complex macrocycle or polycycle that is often fused with the decalin ring, is formed in microbial secondary metabolites. In this manuscript, those secondary metabolites are mainly classified according to the proposed biosynthesis of the decalin moiety-containing compounds: polyketide or isoprenoid biosynthetic derivations. The compounds with polyketide or isoprenoid decalin motifs are further classified according to the features of the remaining side chain or diverse moieties.

\section{Polyketide decalin}

Fungi and bacteria are the major microbial resources that produce the decalin moiety-containing secondary metabolites with a broad spectrum of biological activities. Most of these compounds have a polyketidic decalin scaffold. Frequently, they are highly functionalized through the substitution of methyl, hydroxyl, or $\mathrm{C}=\mathrm{C}$ and $\mathrm{C}=\mathrm{O}$ double bonds on the decalin skeleton, or through a three-, five-, or seven-membered side chain with carboxyls (or its ester), several double bonds, or via ring formation. Furthermore, a pyrone moiety connected to a poly-substituted decalin nucleus by a carbon-carbon bond contributes to an important class of polyketide natural products. In addition, the pyrrolidine-2-one moieties such as tetramic acids and the 4-hydroxy-2-pyridone group are important functionalized units found in many polyketide decalin natural products. The promising biosynthetic potential of fungi is also elaborated here with several examples of macrocyclic or polycyclic compounds.

The biosynthesis of secondary metabolites with a polyketide decalin system is attributed to single or mixed biosynthetic pathways. Specifically, these compounds are proposed to be

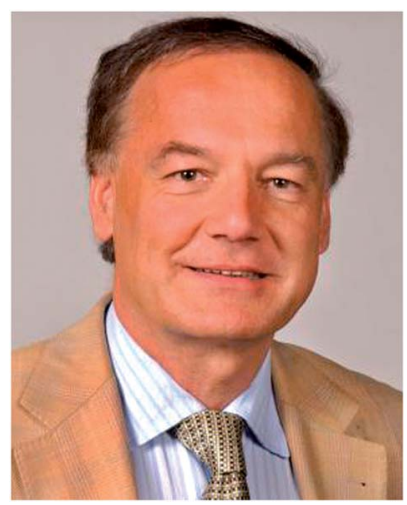

Michael Spiteller received his Diploma in Chemistry (1976) from the Georg-August-Universität in Göttingen, Germany where he earned a doctorate in Chemistry in 1979. After Habilitation in Soil Science, he joined the Institute for Metabolism and Environmental Fate, Bayer Corp., Germany for 8 years as a Group Leader. He then joined the University of Kassel as a full Professor and is now Professor and Head of INFU, TU Dortmund, Germany. He is involved in various projects dealing with natural product drug discovery from plants and endophytes, structural identification of unknown xenobiotics and their metabolites, metabolism of pesticides in the environment, and veterinary drugs. 


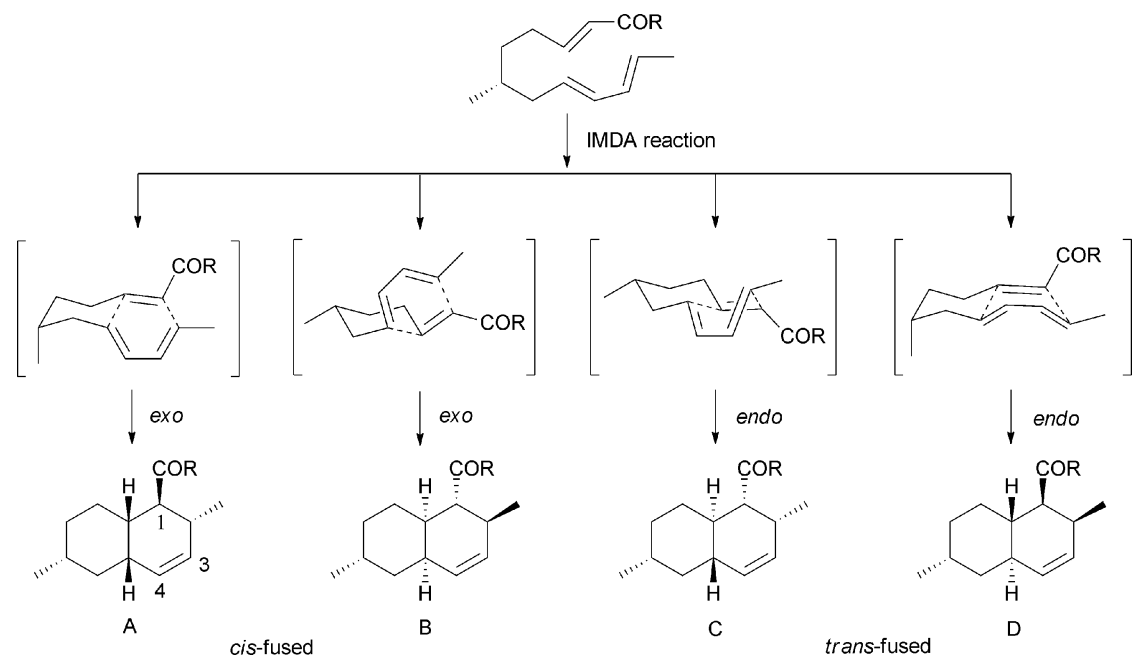

Scheme 1 The IMDA reaction to decalin.

assembled by a linear polyketide unit, which are then cyclized by an enzymatic or non-enzymatic IMDA cycloaddition to form the decalin scaffold. ${ }^{1,7}$ Prior to or after cyclization, many functionalized substituted groups are joined to the above polyketide skeletons which undergo some inter- or intra-molecular reactions to form the complete structure. Amino acids or other unusual units are also occasionally integrated into such a polyketide system to form diverse structures with intriguing structural features.

\subsection{Monacolins}

Monacolins are produced by microorganisms, and show a remarkable inhibition of 3-hydroxy-3-methylglutaryl-coenzyme A (HMG-CoA) reductase that catalyzes the key step in cholesterol biosynthesis. ${ }^{15}$ Lovastatin (1), a cyclic nonaketide acylated by a diketide, and its semisynthetic derivative simvastatin act as potent inhibitors of HMG-CoA reductase and are widely prescribed in the treatment of hypercholesterolemia. ${ }^{16}$ Potent monacolin-type inhibitors of HMG-CoA reductase have been isolated from several fungal strains, mainly Monascus ruber, Aspergillus terreus, and Penicillium citrinum. They share a HMGlike moiety which is linked to the rigid and hydrophobic decalin system, and occupy a portion of the binding site of HMG-CoA, thus blocking access of this substrate (HMG-CoA) to the active site when these potent decalin-type inhibitors are bound. ${ }^{15}$ Until now, about 27 monacolins have been isolated and identified from fungal resources. The decalin skeleton is most likely formed via a biological Diels-Alder reaction by polyketide synthase (PKS) enzymes, as suggested earlier for lovastatin nonaketide synthase (LovB). ${ }^{9}$ This kind of compound is often isolated as an inactive lactone or active hydroxy-acid form. In this review, we will use the word "acid" to describe some lactone-opened monacolins for easy readability.

Lovastatin (1) (also called monacolin K or mevinolin) was first isolated in 1979 as an active inhibitor of HMG-CoA reductase (Endo reported $\mathbf{1}$ as monacolin $\mathrm{K}$ isolated from M. ruber in 1979; $;^{17,18}$ Alberts et al., isolated and reported the same compound as mevinolin isolated from A. terreus ${ }^{19}$ ). The lovastatin biosynthetic gene cluster was first identified in 1999 by the groups of Vederas and Hutchinson. After this work, more attention was paid towards identification of the complete biosynthetic pathway leading to 1 . Recently, the group of Tang ${ }^{16}$ briefly summarized important findings and recent advances on the investigation of the lovastatin (1) biosynthesis, ${ }^{9,20-23}$ and proposed that LovG from the lovastatin (1) gene cluster is responsible for the LovB protein (lovastatin nonaketide synthase, LNKS) turnover and release of dihydromonacolin L (6) (Scheme 2). From the cultures of A. terreus, in addition to $\mathbf{1}$, its lactone-opened form, lovastatin acid (2) (designated as mevinolinic acid) was obtained. ${ }^{19}$ Another lovastatin analog, 4a,5dihydromevinolin (3), a potent hypocholesterolemic agent, was isolated from this fungus. ${ }^{24}$ Two metabolites related to $\mathbf{1}$ were isolated from M. ruber and designated as monacolins $\mathrm{J}(4)$ and $\mathrm{L}$ (5) by Endo et al. ${ }^{25}$ From a mutant strain of M. ruber, dihydromonacolin L (6) and monacolin X (7) were further discovered. ${ }^{26}$ Endo and co-workers also isolated a $\beta$-hydroxybutyryl ester of 4, named monacolin $\mathrm{M}(\mathbf{8}) \cdot{ }^{27} \mathrm{~A}$ hydrolysis derivative of $\mathbf{6}$, identified as $3 \alpha$-hydroxy-3,5-dihydromonacolin L (9), was found to be produced by A. terreus. ${ }^{28}$ Compactin (10) was first isolated from Penicillium brevicompactum in 1976 by Brown et al. as an antifungal metabolite. ${ }^{29}$ In the same year, 10 (designated ML236B) was also isolated as a hypercholesterolemic agent from cultures of the fungus $P$. citrinum. ${ }^{30}$ ML-236A (11) and ML-236C (12) were further isolated from this fungus. Of the three compounds, 10 was most active in inhibiting cholesterol synthesis to $50 \%$ of control at a concentration of $26 \mathrm{nM}$, compared to $280 \mathrm{nM}$ for $\mathbf{1 2}$ and $590 \mathrm{nM}$ for $11 .{ }^{30}$ However, the sodium acid of $\mathbf{1}$ was found to be more than twice as active as the sodium acid of $\mathbf{1 0}$ as an inhibitor of HMG-CoA reductase, with respective $K_{\mathrm{i}}$ values of $0.64 \mathrm{nM}$ and $1.4 \mathrm{nM} .{ }^{19}$ As also shown in an acute assay for rats, the orally administered sodium salt of 1 inhibited cholesterol biosynthesis at a concentration of $46 \mu \mathrm{g}$ $\mathrm{kg}^{-1}$ in $50 \%$ inhibitory dose compared to a $50 \%$ inhibitory dose of $290 \mu \mathrm{g} \mathrm{kg}{ }^{-1}$ for the sodium salt of $10{ }^{19}$ In 1981, Lam et al. 


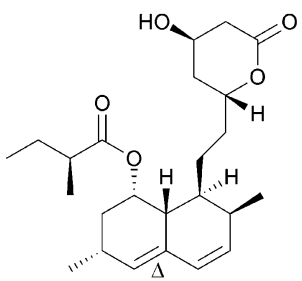

$1 \Delta$ unsaturated

$3 \Delta$ saturated<smiles>[R]C1C[C@@H](C)C=C2C=C[C@H](C)[C@H](CC[C@H]3C[C@@H](O)CC(=O)O3)[C@H]21</smiles><smiles>CC(=O)[C@H](C)C(=O)O[C@H]1C[C@@H](C)C=C2C=C[C@H](C)[C@H](CC[C@H]3C[C@@H](O)CC(=O)O3)[C@H]21</smiles><smiles>CC(O)CC(=O)O[C@H]1C[C@@H](C)C=C2C=C[C@H](C)[C@H](CC[C@H]3C[C@@H](O)CC(=O)O3)[C@H]21</smiles>

8<smiles>CC[C@H](C)C(=O)O[C@H]1CCC=C2C=C[C@H](C)[C@H](CC[C@H]3C[C@@H](O)CC(=O)O3)[C@H]2[C@H]1CC[C@H](O)C[C@H](O)CC(=O)O</smiles>

9

10

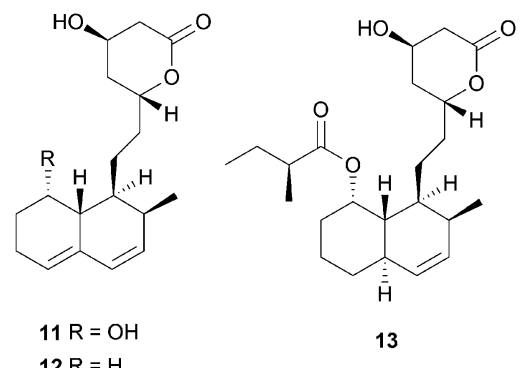

$12 \mathrm{R}=\mathrm{H}$

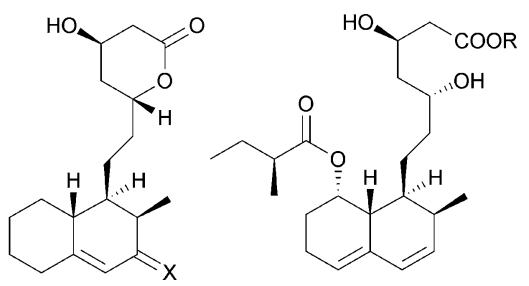

$14 \mathrm{X}=\alpha-\mathrm{OH}, \mathrm{H}$

$15 X=0$<smiles>Cc1ccc2c(c1CC[C@H]1C[C@H](O)CC(=O)O1)CC[C@H](C)C2</smiles>

18<smiles>CC(=O)O[C@H]1C[C@@H](C)C=C2C=C[C@H](C)[C@H](CC[C@H]3CC=CC(=O)O3)[C@H]21</smiles>

20<smiles>CC[C@@H](C)C(=O)O[C@@H]1C[C@@H](C)CC[C@@H]1CC[C@H]1CC=CC(=O)O1</smiles>

$23 \Delta$ saturated $24 \Delta$ unsaturated

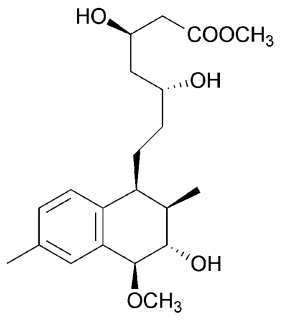

19

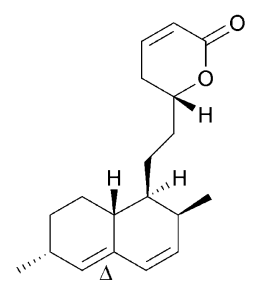

$21 \Delta$ unsaturated

$22 \Delta$ saturated

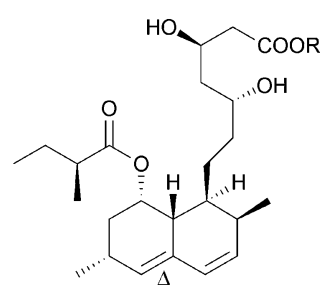

$25 \mathrm{R}=\mathrm{Et}$

$26 \mathrm{R}=\mathrm{Me}$

$27 \mathrm{R}=\mathrm{Me}, \Delta$ saturated discovered 4a,5-dihydrocompactin (13) from the fungus $P$. citrinum. ${ }^{31} 3 \alpha$-Hydroxy-3,5-dihydro-ML-236C (14) was isolated as a white amorphous solid, in its sodium salt form, from
Paecilomyces viridis. ${ }^{32}$ Compound 14 along with 3,5-didydro-3oxo-ML-236C (15), compactin acid (16), and the ethyl ester of compactin (17) were isolated and identified from Eupenicillium 

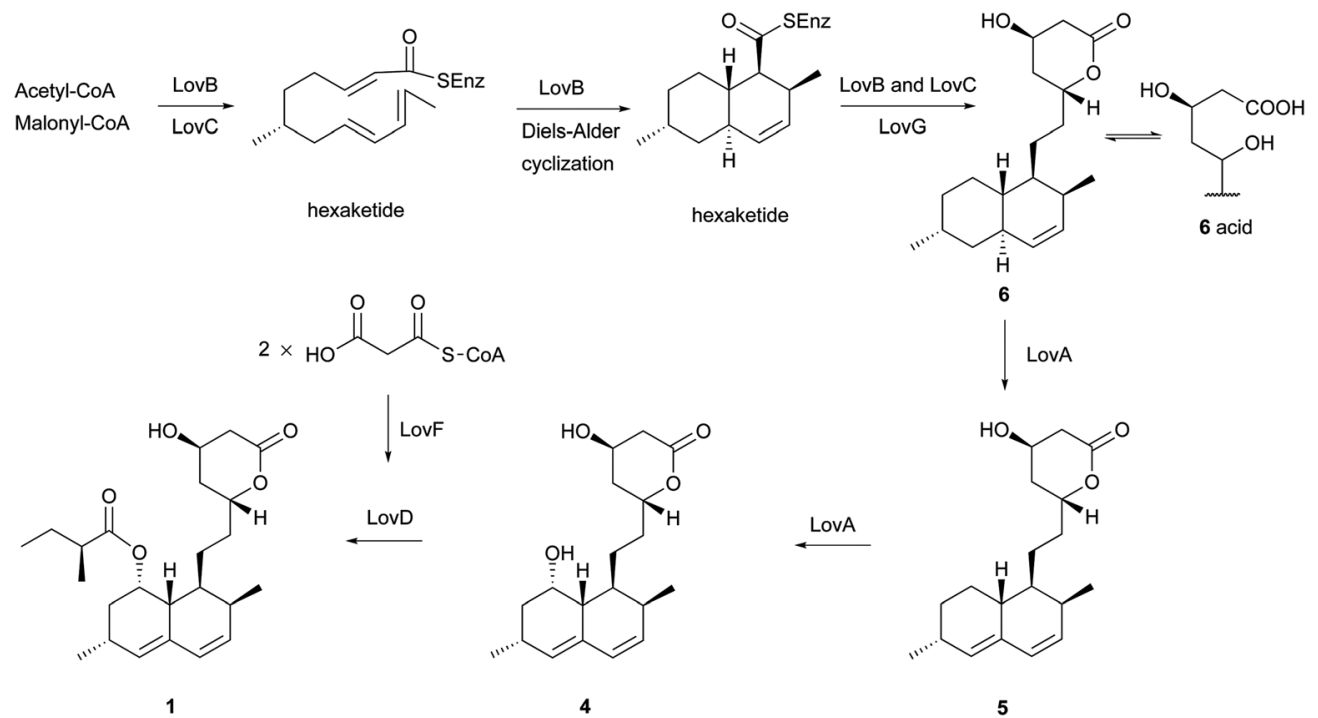

Scheme 2 The proposed biosynthetic pathway for 1

javanicum..$^{33}$ Monacophenyl (18) and aromonacolin A (19), two unusual aromatic monacolin analogs, were isolated from Monascus purpureus-fermented rice (red yeast rice). ${ }^{34,35}$ In the course of further investigation using red yeast rice, five cytotoxic dehydromonacolins, namely dehydromonacolin $\mathrm{N}$ (20), dehydromonacolin L (21), $\alpha, \beta$-dehydrodihydromonacolin L (22), $\alpha, \beta$ dehydrodihydromonacolin $\mathrm{K}$ (23), and dehydromonacolin $\mathrm{K}$ (24), together with the ethyl ester of $\mathbf{1}$ (25), the methyl ester of 1 acid (26) and the methyl ester of 3 (27) were isolated and characterized. ${ }^{36}$<smiles>C[C@H]1C(=O)C=C2C[C@@H](O)CC[C@H]2[C@H]1CCC(=O)O</smiles>

28<smiles>C[C@H]1CC[C@H]2C=C[C@H](C)[C@H](/C=C/C(=O)O)[C@H]2C1</smiles>

$32 \Delta$ saturated

$34 \Delta$ unsaturated<smiles></smiles>

36

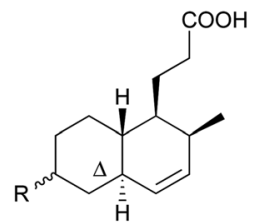

$29 \mathrm{R}=\beta-\mathrm{OH}$

$30 \mathrm{R}=\alpha-\mathrm{Me}$

$31 \mathrm{R}=\alpha-\mathrm{Me}, \Delta$ unsaturated

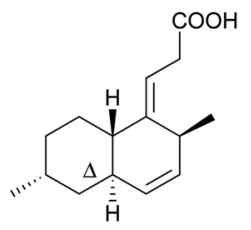

$33 \Delta$ saturated

$35 \Delta$ unsaturated

\subsection{Monacolin derivatives}

Simple decalin derivatives are usually found in monacolinproducing fungi. From the biosynthetic point of view, they are presumed to be formed by $\beta$-oxidation or/and dehydrogenation of monacolins. ${ }^{37}$

Antifungal activity-guided fractionation led to the isolation of the two decalin derivatives, eujavanoic acids A (28) and B (29) from $E$. javanicum. ${ }^{33}$ A heptaketide (30) and a decalin derivative, monascusic acid A (31) were isolated from red yeast rice fermented by $M$. purpureus. ${ }^{38}$ Further chemical investigation using red yeast rice provided five new decalin derivatives, monascusic acids B-E (32-35) and monascusic lactone A (36). ${ }^{37} \quad 30-34$ showed the immunosuppressive effect on human $\mathrm{T}$ cell proliferation in a dose-dependent manner from 10 to $100 \mu \mathrm{M} \cdot{ }^{37}$ Compound 36 , the first reported naturally-occurring decalin derivative possessing a spiro lactone at the C-1 position, is biosynthetically related to monacolin $\mathrm{L}$ (Scheme 3).

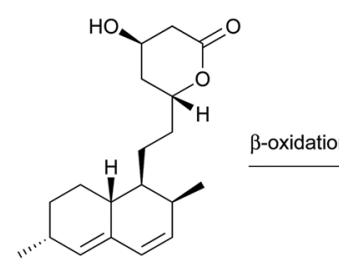<smiles>C[C@H]1C=C2C=C[C@H](C)[C@H](CCC(=O)O)[C@@H]2CC1</smiles>

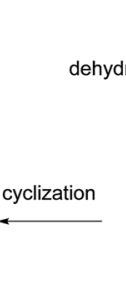

36

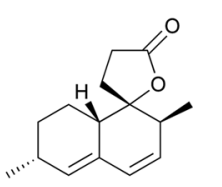

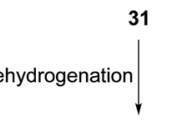<smiles>C[C@H]1C=CC2=C[C@H](C)CC[C@H]2/C1=C/CC(=O)O</smiles>

35
Scheme 3 The proposed biosynthesis of 36 . 


\subsection{Side chains with a 3-oxopropanol or its derivative}

The skeleton of these compounds could have the same construction pattern from some acetate units via a polyketide pathway, and like lovastatin (1) biosynthesis, an intramolecular Diels-Alder reaction seems to be responsible for their decalin scaffold formation. They share a highly substituted polyfunctionalized trans-decalin, which is modified by methyls, hydroxyl, double bond and side chain groups or moieties. More importantly, the side chain with a $\beta$-ketoaldehyde seems to be crucial for some biological activities.

Stemphyloxin I (37) and II (38), two nonspecific phytotoxic ferric ion chelates, were isolated from the plant pathogenic fungus Stemphylium botryosum..$^{39-41}$ They are highly functionalized trans-decalin derivatives and exhibited high toxicity towards tomato and eggplant. The presence of $\beta$-ketoaldehyde functional group appears to be crucial for both toxicity and chelation of iron. ${ }^{42}$ Six phytotoxins, betaenones A-F (39-44), have been isolated from the cultures of Phoma betae, a fungus causing leaf spot disease of sugar beet. ${ }^{\mathbf{4 3 , 4 4}}$ The biosynthesis of 40 involving an intramolecular Diels-Alder reaction was studied using feeding experiments (Fig. 1). ${ }^{45,46}$

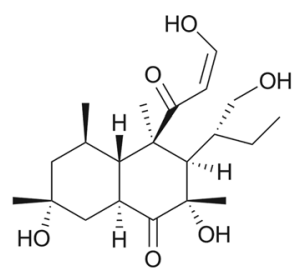

37

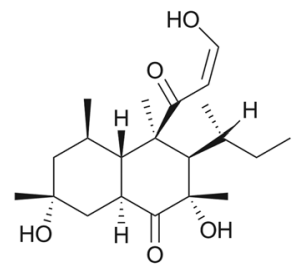

41

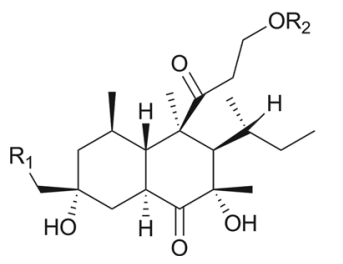

$40 \mathrm{R}_{1}=\mathrm{H}, \mathrm{R}_{2}=\mathrm{H}$

$42 \mathrm{R}_{1}=\mathrm{OH}, \mathrm{R}_{2}=\mathrm{H}$

$44 \mathrm{R}_{1}=\mathrm{H}, \mathrm{R}_{2}=\mathrm{Ac}$
From the marine sponge-derived fungus Trichoderma harzianum, trichoharzin (45) with an alkylated trans-decalin skeleton was found. ${ }^{47}$ Phomodiol (46), an antifungal polyketide, has been found in Phomopsis sp. ${ }^{48}$ In a screening of soil microorganisms for new antibiotics, aldecalmycin (47) with high efficacy against Gram-positive bacteria was obtained from a culture broth of Streptomyces sp. ${ }^{49}$ Australifungin (48), structurally related to 37, was isolated from a fungus Sporormiella australis and exhibited strong antifungal activity against a panel of clinically relevant Aspergillus, Candida, and Cryptococcus strains

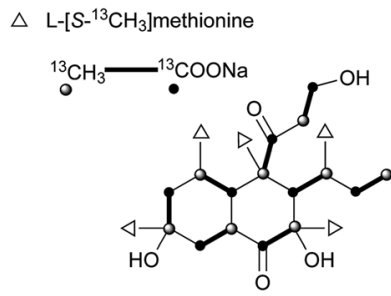

Fig. 1 Biosynthetic origins of carbons in 40

with minimum inhibitory concentration (MIC) values ranging from 0.015 to $1.0 \mu \mathrm{g} \mathrm{mL}{ }^{-1} .^{50}$ It was also the first reported nonsphingosine-based inhibitor of sphingolipid biosynthesis.<smiles>CC[C@H](C)[C@]1([C@@H](C)CCO)C=C[C@H]2[C@@H](O)[C@@H](OC(=O)/C=C(\C)CC(=O)O)C[C@@H](C)[C@]2(C)[C@H]1C(=O)CCO</smiles>

45

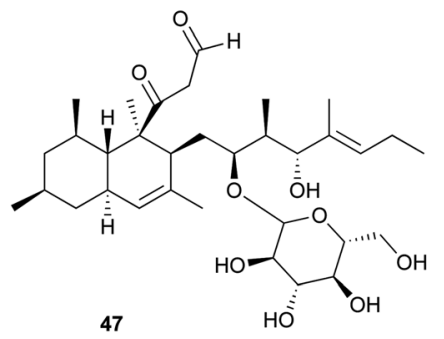<smiles>CCCCCC[C@H](C)C1=C(O)C(=O)[C@H]2[C@@H](O)[C@H](C)C[C@H](O)[C@H]2[C@H](C(=O)/C=C\O)[C@H]1C</smiles>

48<smiles>C[C@H]1CC[C@H]2C=C[C@H](C)[C@H](C(=O)C(O)CO)[C@H]2C1</smiles>

46<smiles>CC[C@H](C)C1C=C[C@H]2[C@@H](O)[C@@H](OC(=O)/C=C(\C)CC(=O)O)C[C@@H](C)[C@]2(C)[C@H]1C(C)=O</smiles>

49

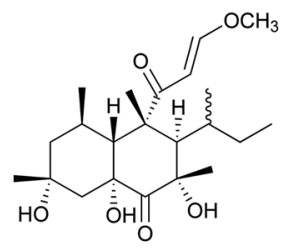

50

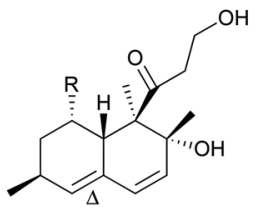

$52 \mathrm{R}=\mathrm{OH}$

$53 \mathrm{R}=\mathrm{OH}, \Delta$ saturated

$55 \mathrm{R}=\mathrm{H}, \Delta$ saturated

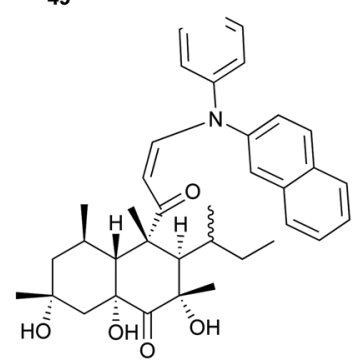

51<smiles>C[C@H]1C=C2C=C[C@@]3(C)OCCC(=O)[C@]3(C)[C@H]2[C@@H](O)C1</smiles> 
Another polyketide, deoxynortrichoharzin (49) was obtained from the saltwater culture of Paecilomyces cf. javanica isolated from the marine sponge Jaspis cf. coriacea, which did not show any cytotoxic activity against solid tumor cells in culture. ${ }^{51}$ Two betaenone derivatives, 10-hydroxy-18-methoxybetaenone (50) and 10-hydroxy-18- $N$-2-naphtyl- $N$-phenylaminobetaenone (51) were produced by an undescribed fungus of the genus Microsphaeropsis isolated from the Mediterranean sponge Aplysina aerophoba. $^{52}$ Derivative $\mathbf{5 0}$ showed inhibitory activity against PKC- $\varepsilon$, CDK4, and EGF receptor tyrosine kinases, with $\mathrm{IC}_{50}$ values of $36.0,11.5$, and $10.5 \mu \mathrm{M}$, respectively, whereas 51 did not. Decumbenones A (52) and B (53), together with versiol (54) were isolated from the fungus, Penicillium decumbens. ${ }^{53}$ Only one of them, compound 52, inhibited melanization in Magnaporthe grisea, the rice blast pathogen, suggesting the importance of the structural units of the diene and $\mathrm{COCH}_{2} \mathrm{CH}_{2} \mathrm{OH}$ for its inhibition efficacy.

Aspermytin A (55), a heptaketide with a trans-decalin framework, was reported from a cultured marine fungus, Aspergillus sp., inhabiting the mussel Mytilus edulis. ${ }^{54}$ It induced significant neurite outgrowth in rat pheochromocytoma (PC-12) cells at concentration of $50 \mu \mathrm{M}$. FR225654 (56), a novel gluconeogenesis inhibitor was isolated from the culture of Phoma sp. ${ }^{55}$ Eujavanicols A-C (57-59) were purified from an antifungal-active fraction of $E$. javanicum, but showed no antifungal activity. ${ }^{56}$ More recently, Tandyukisin (60), a novel decalin derivative with an enolic $\beta$-ketoaldehyde, was produced by a marine sponge-derived fungus, T. harzianum. ${ }^{57}$ It exhibited moderate cytotoxic activity against the murine P388 leukemia, the human HL-60 leukemia,

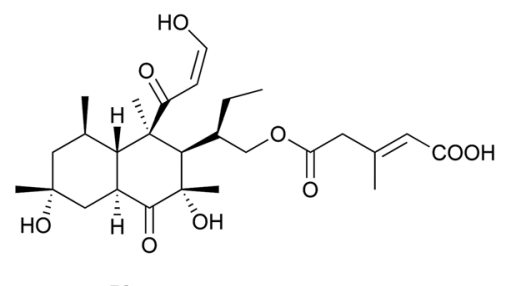

56

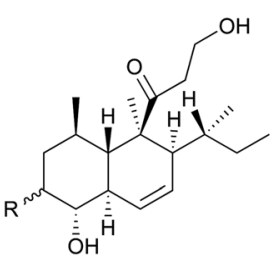

$57 \mathrm{R}=\alpha-\mathrm{OH}$ $58 \mathrm{R}=\beta-\mathrm{OH}$

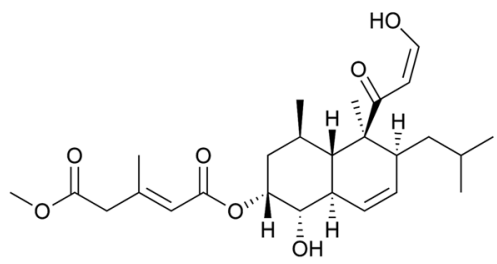

60 and the murine $\mathrm{L} 1210$ leukemia cell lines with $\mathrm{IC}_{50}$ values ranging from 41 to $55 \mathrm{mM}$.

\subsection{Side chains with a pentanedienoic acid}

Most of these carboxylic acids have been detected in the cultures of Penicillium species, and possess a penta-2,4-dienoic acid unit connected to a trans-decalin, showing a plethora of interesting activities. A few cis-decalin skeletons can also be found, which seems to play an important role for their relevant biological activities.

Tanzawaic acids A-D (61-64) from Penicillium citrinum, ${ }^{58}$ tanzawaic acids E (65) and F (66) from a marine-derived strain of Penicillium steckii, ${ }^{59}$ tanzawaic acids $\mathrm{G}(67)$ and $\mathrm{H}(68)$ from an endophytic fungus $P$. citrinum, ${ }^{60}$ and tanzawaic acids I-L (69-72) from a soil derived Penicillium sp. ${ }^{61}$ are representative trans-decalin pentanedienoic acids. Among metabolites 61-64, only 62 significantly inhibited superoxide anion production in human neutrophils $\left(\mathrm{IC}_{50}=26 \mu \mathrm{g} \mathrm{mL}{ }^{-1}\right) .^{58}$ Acids 67 and 68 exhibited no cytotoxicity on the growth of the L5178Y mouse lymphoma cell line $\left(\mathrm{IC}_{50}>10 \mu \mathrm{M}\right)$ and no antimicrobial activity against Staphylococcus aureus, Streptococcus pneumoniae, and Escherichia coli at a concentration of $64 \mu \mathrm{g} \mathrm{mL}{ }^{-1} .^{60}$ Compounds 61, 65, and 71 showed inhibition of the conidial germination in the rice blast fungus Magnaporthe oryzae at concentrations of around $25 \mu \mathrm{g} \mathrm{mL}{ }^{-1}{ }^{61}$ Ōmura and co-workers reported five anticoccidial agents: hynapenes A-C (73-75), from a soil-inhabiting Penicillium sp. that were effective against monensin-resistant Eimeria tenella, ${ }^{62}$ and arohynapenes A (76) and B (77) from a water-inhabiting Penicillium sp. ${ }^{63}$ Bioassay-guided fractionation led to the isolation of coprophilin (78), a trans-decalinpentanoic acid methyl ester from an unidentified fungus. ${ }^{64} \mathbf{7 8}$, as a anticoccidial agent, inhibited the growth of E. tenella with an MIC value of $1.5 \mu \mathrm{M}$, compared to that of $123 \mu \mathrm{M}$ for $73,34.7 \mu \mathrm{M}$ for 74 and 75, $35 \mu \mathrm{M}$ for 76, and $7.0 \mu \mathrm{M}$ for $77 .{ }^{62,63}$ Phomopsidin (79) with a cis-decalin core, was obtained from Phomopsis sp., and is a new inhibitor of the assembly of microtubule proteins at an $\mathrm{IC}_{50}$ of $5.7 \mu \mathrm{M} .{ }^{65}$ Using ${ }^{13} \mathrm{C}$-labeled precursors, 79 was proposed to be a trimethylated nonaketide (Fig. 2). ${ }^{66}$ Biological tests for many structurally related compounds 61-64 suggested that the cis-decalin structure of $\mathbf{7 9}$ is important for the anti-microtubule activity. ${ }^{66}$ In antisense-based screening strategies, pannomycin (80) was isolated from Geomyces pannorum. ${ }^{67}$ It exhibited weak antibacterial activity.

\subsection{Decalins with oxygenated diene/triene/tetraene side chains}

These kinds of decalin derivatives are highly methylated and oxygenated polyketides, and typically have a 6-, 7-, or 9membered side chain similar to pentanedienoic acids.

A weakly antifungal polyketide, fusarielin A (81), and three biosynthetically related fusarielins B-D (82-84), were isolated from Fusarium sp. ${ }^{68}$ Dehydroxychlorofusarielin B (85) is a mild antibacterial compound isolated from the marine-derived fungus Aspergillus sp. ${ }^{69}$ In addition, 81 and 82 were also isolated from this fungus and demonstrated weak antibacterial activity. ICM0301A-H (86-93) were inhibitors of angiogenesis in human 
<smiles>[R]C1Cc2ccc(C)c(/C=C/C=C/C(=O)O)c2[C@H](C)C1</smiles><smiles>[R]C1[C@H](C)C=C[C@H]2C[C@@H](C)C[C@@H](C)[C@H]2[C@H]1/C=C/C=C/C(=O)O</smiles>

$61 \mathrm{R}=\mathrm{H}$

$64 \mathrm{R}=\mathrm{OH}$

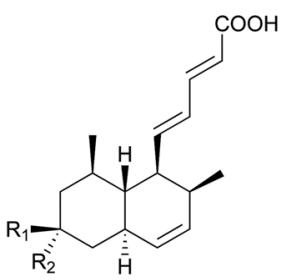

$65 \mathrm{R}_{1}=\mathrm{Me}, \mathrm{R}_{2}=\mathrm{OH}$

$66 \mathrm{R}_{1}=\mathrm{COOH}, \mathrm{R}_{2}=\mathrm{H}$<smiles>CC1=C[C@H](O)[C@H]2C[C@H](CO)C[C@H](C)[C@]2(C)[C@H]1/C=C/C=C/C(=O)O</smiles>

68<smiles>CC1CC(C)C2(C)C(C=C[C@](C)(O)C2/C=C/C=C/C(=O)O)C1</smiles>

71
$62 \mathrm{R}=\mathrm{H}$

$63 \mathrm{R}=\mathrm{OH}$<smiles>CC1C[C@@](C)(O)Cc2ccc(CO)c(/C=C/C=C/C(=O)O)c21</smiles>

67

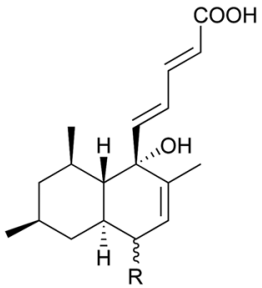

$69 \mathrm{R}=\beta-\mathrm{OH}$

$70 \mathrm{R}=\alpha-\mathrm{OH}$

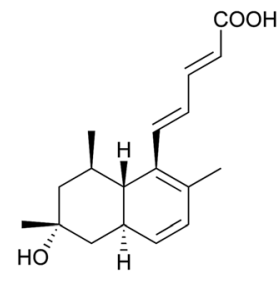

72<smiles>CC1CC(C)C2C(C1)C(O)C(O)C(C)C2(C)/C=C/C=C/C(=O)O</smiles>

73<smiles>CC1CC(=O)C2(C(=O)C(C)(C)C=CC2C)C(C)C1</smiles>

75<smiles>CC(=O)C=CC=C[C@H]1[C@H](C)C=C[C@@H]2C[C@H](C)[C@@H](O)[C@H](C)[C@]21C</smiles>

78<smiles>CC1=C(/C=C/C=C/C(=O)O)C2C(C)CC(C)CC2CC(=O)C1C</smiles>

74<smiles>[R2]Cc1ccc2c(c1/C=C/C=C/C(=O)O)[C@H](C)C[C@@H](C)[C@H]2[Z19]</smiles>

$76 \mathrm{R}_{1}=\mathrm{OH}, \mathrm{R}_{2}=\mathrm{H}$

$77 \mathrm{R}_{1}=\mathrm{H}, \mathrm{R}_{2}=\mathrm{OH}$<smiles>C/C=C(\C)[C@H]1C(C)=C[C@H]2[C@@H](O)CC[C@H](C)[C@H]2[C@H]1/C=C/C=C/C(=O)O</smiles>

79<smiles>C/C=C/[C@H]1C(C)=C[C@H]2C[C@H](C)[C@@H](O)C[C@H]2[C@H]1C=C(C)/C=C/C(=O)O</smiles>

80

umbilical vein endothelial cells (HUVECs) with $\mathrm{IC}_{50}$ values of 2.2-9.3 $\mu \mathrm{g} \mathrm{mL} \mathrm{m}^{-1} .^{70}$ Six fungal-derived polyketides, cladobotric acids A-F (94-99), were isolated from a Cladobotryum species from New Zealand. ${ }^{71}$ All of them showed modest growth

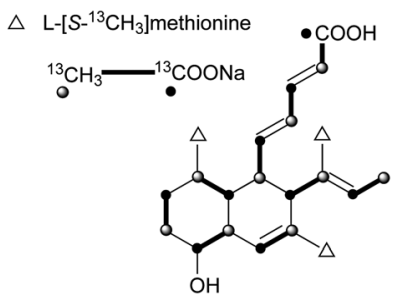

Fig. 2 Biosynthetic origins of carbons in 79. inhibition against the murine $\mathrm{P} 388$ leukemia cell line with $\mathrm{IC}_{50}$ values of $6.6,27.8,19.4,24.9,1.4$, and $15.6 \mu \mathrm{M}$, respectively, and were even active against Bacillus subtilis and Candida albicans. Furthermore, compound $\mathbf{9 8}$ was active against Trichophyton mentagrophytes and Cladosporium resinae. Feeding experiments with ${ }^{13} \mathrm{C}$-labeled precursors disclosed their polyketide biosynthesis from 11 intact $\mathrm{C}_{2}$ units (Fig. 3). ${ }^{69,71}$ Antifungal bioassayguided isolation yielded two new cis-decalin derivatives, 100 and 101, from an endophytic Penicillium sp. isolated from the inner bark of the Pacific yew tree, Taxus brevifolia. ${ }^{72}$ Both were selectively active against the plant pathogen Sclerotinia sclerotiorum $\left(17 \mathrm{~mm}\right.$ zone at $1.1 \times 10^{-4} \mu \mathrm{mol} / \mathrm{disk}$ for $100 ; 16 \mathrm{~mm}$ zone at 3.4 $\times 10^{-4} \mu \mathrm{mol} / \mathrm{disk}$ for 101). In a screening program for potent compounds inducing osteoblast differentiation in C3H10T1/2 cells, decalpenic acid (102) bearing a tetraenoic acid side chain 


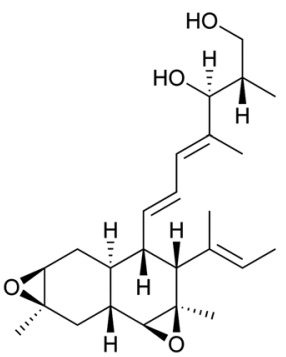

81

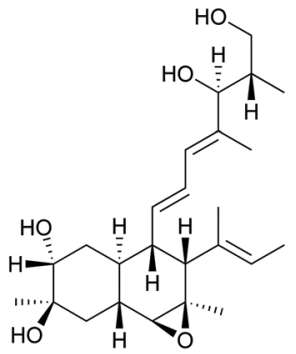

82<smiles>C/C=C(\C)[C@@H]1C(C)=C[C@H]2C[C@@]3(C)O[C@@H]3C[C@H]2[C@H]1/C=C/C=C(\C)C(O)[C@H](C)CO</smiles>

83

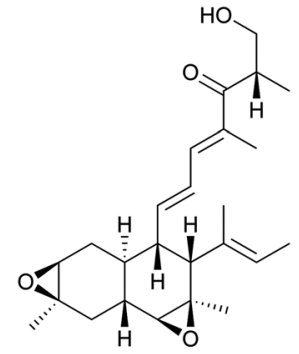

84

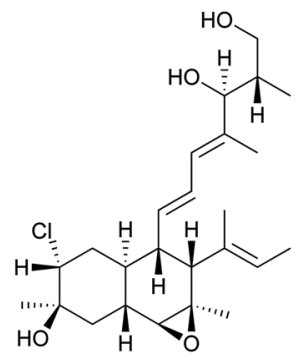

85

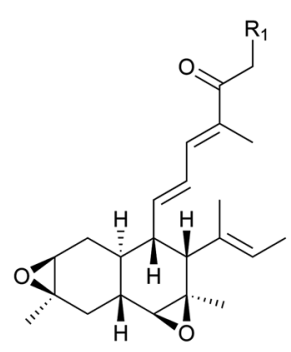

$86 R_{1}=M e$

$87 \mathrm{R}_{1}=\mathrm{H}$

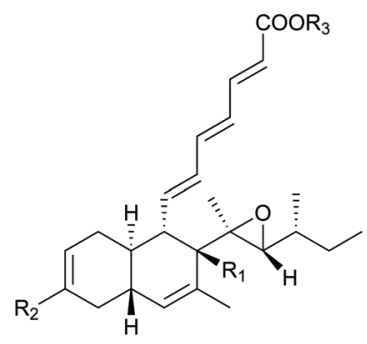

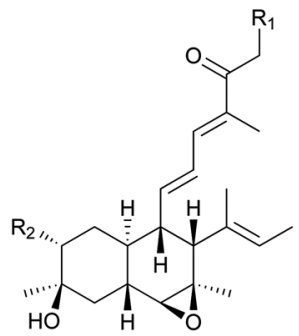

$88 \mathrm{R}_{1}=\mathrm{Me}, \mathrm{R}_{2}=\mathrm{Cl}$

$89 \mathrm{R}_{1}=\mathrm{H}, \mathrm{R}_{2}=\mathrm{Cl}$

$90 \mathrm{R}_{1}=\mathrm{Me}, \mathrm{R}_{2}=\mathrm{H}$

$91 R_{1}=H, R_{2}=H$

$92 \mathrm{R}_{1}=\mathrm{H}, \mathrm{R}_{2}=\mathrm{OMe}$

$93 \mathrm{R}_{1}=\mathrm{H}, \mathrm{R}_{2}=\mathrm{OH}$

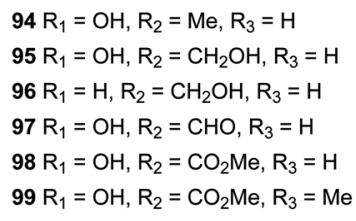<smiles>CC1=C[C@H]2C[C@@H](C)C(O)[C@H](C)[C@H]2[C@H](/C=C(C)/C=C(C)/C=C/C(=O)O)/C1=C/C(=O)CO</smiles>

100<smiles>CC1=C[C@H]2C[C@@H](C)[C@H](O)[C@H](C)[C@H]2[C@H](/C=C(C)/C=C(C)\C=C\C(=O)O)/C1=C/C(=O)CO</smiles>

101<smiles>CCC[C@H]1C=C[C@H]2CC(C)=CC[C@H]2[C@]1(C)/C=C(C)/C=C/C=C/C=C/C(=O)O</smiles>

102 was isolated from Penicillium verruculosum. ${ }^{73}$ Through activation of retinoic acid receptor $\gamma$, it induces early osteoblastic markers in pluripotent mesenchymal cells. ${ }^{74}$

\subsection{Pyrone derivatives}

Pyrone derivatives are formed when the pyrone ring is substituted by the methoxyl, aldehyde, hydroxymethyl, amino or ethanolamide group and connected to the decalin framework directly via carbon-carbon bond. Most of these decalin derivatives possess the cis-decalin system. The modified decalin motif with two types of relative configurations has been proposed to be formed via a biological intramolecular Diels-Alder reaction to give exo or endo products. ${ }^{75,76}$

Solanapyrones A-E (103-107), the phytotoxins, were isolated from the fungus Alternaria solani which causes early blight disease in tomato and potato plants. ${ }^{77-79}$ Phytotoxin 103 was reported to be an inhibitor of DNA polymerase $\beta$ and $\gamma$, with $\mathrm{IC}_{50}$ values of 30 and $37 \mu \mathrm{M}$, respectively. ${ }^{78}$ The biosynthetic pathway for $\mathbf{1 0 3}$ was investigated by feeding experiments and gene expression studies (Scheme 4). ${ }^{10,76,79}$ The decalin scaffold of $\mathbf{1 0 6}$ and $\mathbf{1 0 7}$ was first synthesized by a domino Michael reaction (Scheme 5). ${ }^{80}$ In order to complete the total synthesis of 103 and 104, Lygo et al. reported an 


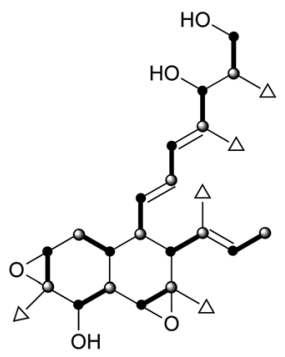

81

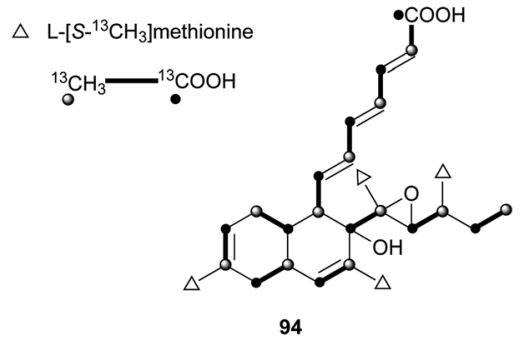

Fig. 3 Biosynthesis of 81 and 94 on the basis of the data from feeding experiments.

optimized IMDA cycloaddition to the decalin fragment (Scheme 6). ${ }^{81}$ MacMillan and co-workers developed a new powerful organocatalytic IMDA reaction protocol to achieve the asymmetric synthesis of 106 (Scheme 7). ${ }^{82}$ Chemical investigation of an unidentified filamentous marine fungus led to the isolation of new phytotoxic compounds, solanapyrones E-G (108-110) and the known compound 105. ${ }^{83}$ Compound 108, with a cis-decalin unit, has the same compound name as the trans-decalin derivative 107. Solanapyrones J-M (111-114), new solanapyrone analogues with modest antifungal and antibacterial activities, were obtained from an unidentified fungicolous fungus. ${ }^{\mathbf{8 4}}$ Nigrosporapyrones A-C (115-117) were isolated from the marine-derived fungus Nigrospora. ${ }^{\mathbf{8 5}}$ Compound 115 exhibited a weak antibacterial activity with an MIC value of $128 \mu \mathrm{g} \mathrm{mL}^{-1}$.

\subsection{Macrolides}

Nodusmicin (118) and nargenicin (119) represent a class of macrolide antibiotics that were isolated from Saccharopolyspora hirsuta by Whaley et al. in $1980^{86}$ and from Nocardia argentinensis by Celmer et al. in the same year, respectively. ${ }^{\mathbf{8 7}}$ They possess a ten-membered lactone ring fused to an oxygenbridged cis-decalin system. The acetylated products, 18-O-acetylnodusmicin (120) and 18-O-acetylnargenicin (121), were also isolated and identified from $N$. argentinensis. ${ }^{88}$ A more complex analog, coloradocin (122) (luminamicin) with an additional 14membered macrolactone containing an enol ether in conjugation with an unsaturated cyclic anhydride functionality, was found from the actinomycete strains, Actinoplanes coloradoensis and Nocardioides sp. ${ }^{89}$ Compound 122 showed selective activity against anaerobic and microaerophilic bacteria whereas compounds 118 and 119 inhibited some aerobic bacteria, thereby suggesting the importance of the additive macrocyclic moiety. ${ }^{90}$ The biosynthetic origin of this family was investigated

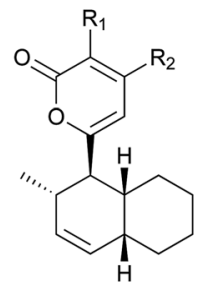<smiles>[R]c1c(OC)cc([C@H]2[C@@H](C)C=C[C@H]3CCCC[C@@H]32)oc1=O</smiles>

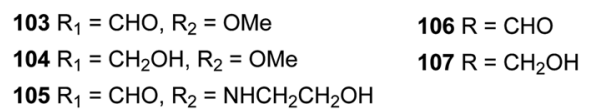<smiles>[R]C1([R2])CC[C@]2(C)[C@@H](C=C[C@@H](C)[C@H]2c2cc(N)c(C(=O)O)c(=O)o2)C1</smiles><smiles>[R7]c1c(OC)cc([C@]2(C)[C@H](C)C=C[C@H]3CCC[C@H]([R20])[C@H]32)oc1=O</smiles>

$$
\begin{aligned}
& 108 R_{1}=O H, R_{2}=H \\
& 109 R_{1}=H, R_{2}=O H \\
& 110 R_{1}=H, R_{2}=H
\end{aligned}
$$

$111 \mathrm{R}_{1}=\mathrm{CHO}, \mathrm{R}_{2}=\alpha-\mathrm{Me}$<smiles>[R]N/C=C1/C(=O)C=C([C@]2(C)[C@@H](C)C=C[C@H]3[C@H](C)CCC[C@H](C)[C@]32C)OC1=O</smiles>

$114 \mathrm{R}_{1}=\mathrm{CH}_{2} \mathrm{OH}, \mathrm{R}_{2}=\beta-\mathrm{Me}$

$$
\begin{array}{ll}
112 \mathrm{R}=\mathrm{CH}_{2} \mathrm{CH}_{2} \mathrm{OH} & 115 \mathrm{R}_{1}=\mathrm{OH}, \mathrm{R}_{2}=\mathrm{H}, \mathrm{R}_{3}=\mathrm{OMe} \\
113 \mathrm{R}=\mathrm{H} & 116 \mathrm{R}_{1}=\mathrm{OH}, \mathrm{R}_{2}=\mathrm{H}, \mathrm{R}_{3}=\mathrm{NHCH}_{2} \mathrm{CH}_{2} \mathrm{OH} \\
& 117 \mathrm{R}_{1}=\mathrm{H}, \mathrm{R}_{2}=\mathrm{OH}, \mathrm{R}_{3}=\mathrm{NHCH}_{2} \mathrm{CH}_{2} \mathrm{OH}
\end{array}
$$

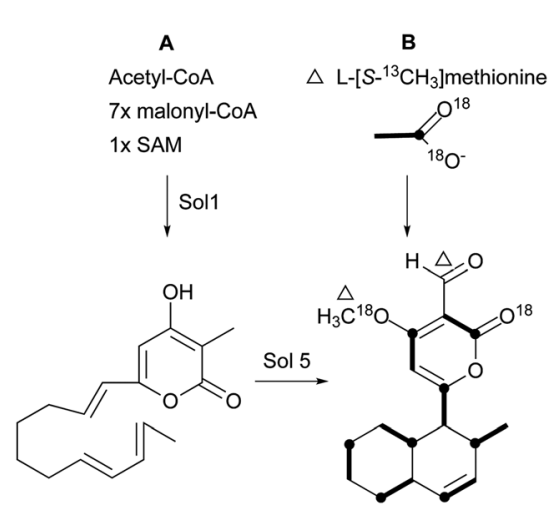

Scheme 4 (A) The prosolanapyrone synthase (PSS) encoded by Sol1 catalyzes octaketide prosolanpyrone formation and then a flavindependent oxidase (solanapyrone synthase, SPS) encoded by Sol5 catalyzes Diels-Alder cyclization to form 103. (B) Incorporation of labeled acetate and methionine into 103. 


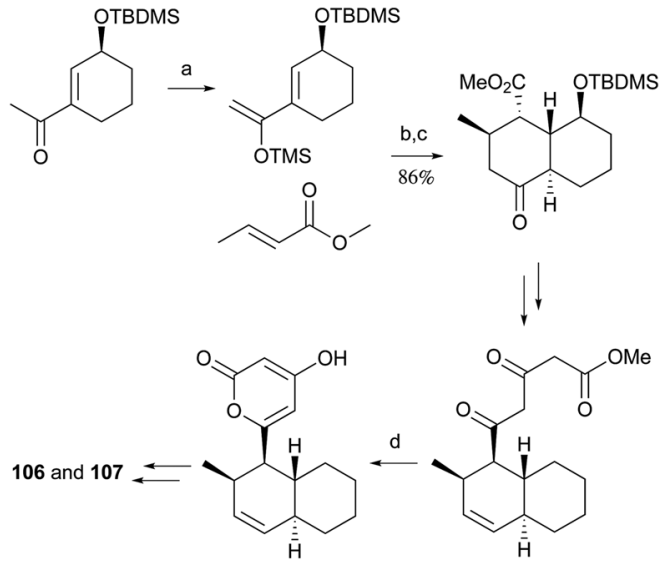

Scheme 5 The first total syntheses of 106 and 107: the domino Michael reaction to decalone and the general biosynthetic strategy of pyrone. (a) LDA, TMSCl, 93\%; (b) MeLi, methyl crotonate, HMPA, THF; (c) $\mathrm{MeONa}, \mathrm{MeOH}$; (d) $\mathrm{DBU}$, benzene, $93 \%$.
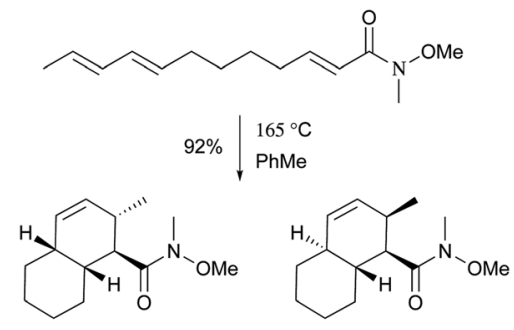

exo: endo $=3: 1$

Scheme 6 The exo-selective thermal Diels-Alder reaction used for the total syntheses of 103 and 104 .
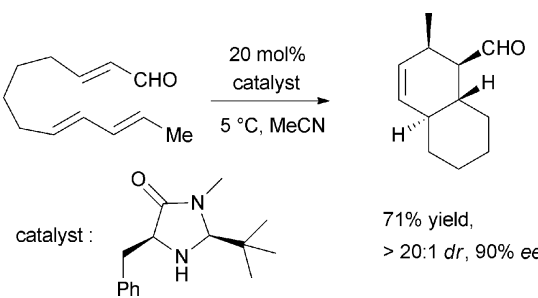

$71 \%$ yield

$>20: 1 d r, 90 \%$ ee

Scheme 7 MacMillan's effective organocatalytic IMDA reaction to the decalin scaffold in the total synthesis of 106

through feeding experiments, as shown for compound 122 in Fig. $4 .^{\mathbf{8 8 , 9 1}}$ Compared with the assembly of a polyketide chain in compounds 118-121, 122 also involves an acetate and a succinate unit incorporated into the additional 14-membered macrolactone.

In a broad screening program for active secondary metabolites produced by myxobacteria, Sorangium cellulosum was found to produce a novel polyketide, chlorotonil A (123), with a unique gem-dichloro-1,3-dione functionality in a 14membered macrolide ring fused to an unsaturated trans-decalin. ${ }^{92}$ The total synthesis of $\mathbf{1 2 3}$ was reported by Rahn and Kalesse in the same year. ${ }^{93}$ The decalin system was prepared by

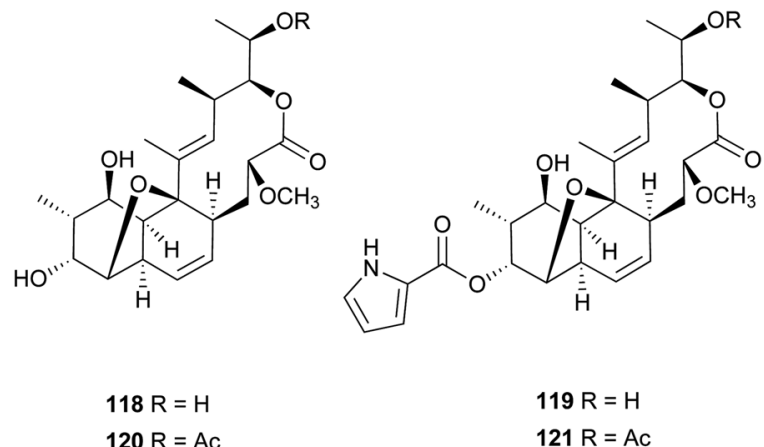

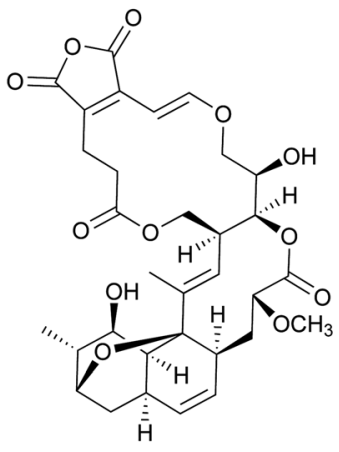

122

a highly stereoselective halogen (bromine)-directed DielsAlder reaction over standard Diels-Alder routes (Scheme 8). More recently, antibacterial activity-guided fractionation yielded the antibiotic anthracimycin (124) from a Streptomyces species isolated from near-shore marine sediments by the group of Fenical. ${ }^{94}$ It exhibited significant inhibition of Grampositive pathogens such as Bacillus anthracis and clinicallyrelevant methicillin-resistant $S$. aureus (MRSA) with MIC values of 0.031 and $0.06 \mu \mathrm{g} \mathrm{mL} \mathrm{m}^{-1}$, respectively. The semisynthetic derivative, dichloro-anthracimycin has similar activity against Gram-positive pathogenic bacteria as 124, but is active against Gram-negative pathogens. However, 124 lacked activity against Gram-negative pathogens or was weakly active against them. The biosynthesis of compounds 123 and 124 could be proposed via a polyketide pathway with 11 acetate units.

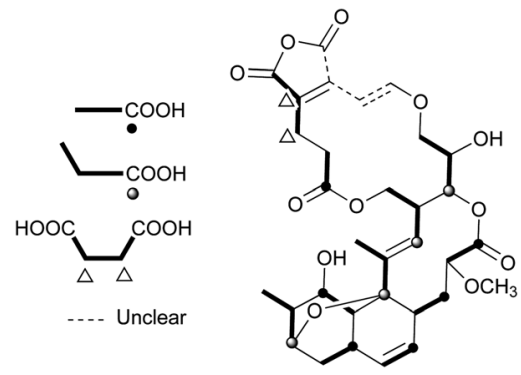

Fig. 4 Biosynthetic origin of 122 on the basis of the data from feeding experiments. 
A)

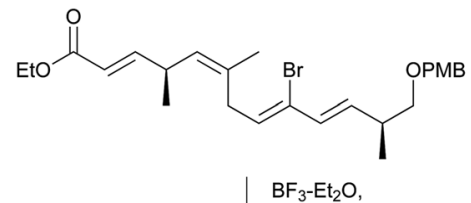

$\checkmark$ toluene, $85^{\circ} \mathrm{C}, 58 \%$

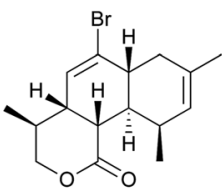

$13: 1 d r$

B)
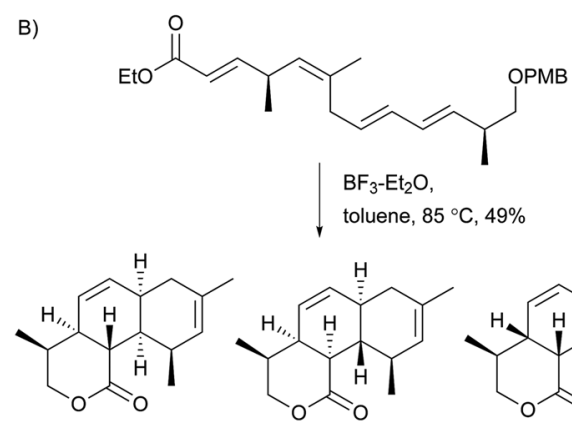

1
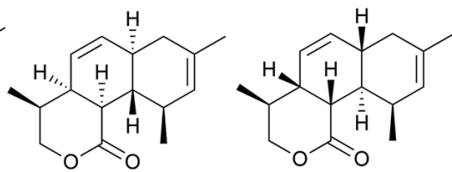

Scheme 8 Synthesis of the decalin system in compound 123. A) Highly stereoselective halogen (bromine)-directed Diels-Alder reaction. B) The same reaction condition without bromine substituent.

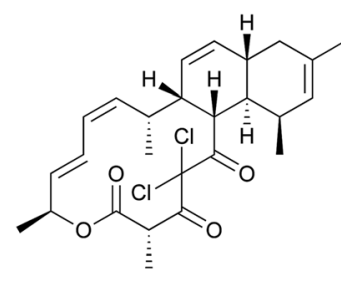

123

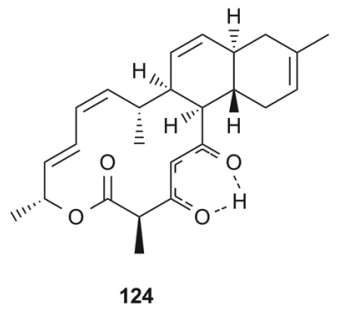

124

\subsection{Pyrrolidine-2-one}

Pyrrolidine-2-one, an important biologically active moiety, is often found in fungal metabolites arising from the mixed PKSnonribosomal peptide synthetase (NRPS) pathway and has been reported in several reviews. ${ }^{95-97}$ However, to the best of our knowledge, there is a dearth of information on pyrrolidine-2one metabolites. Here, we highlight all those compounds that preferentially cooperate with a decalin system. Decalin-type pyrrolidine-2-one derivatives are comprised of two important biosynthetic units. The first one is a linear $\mathrm{C}_{14}, \mathrm{C}_{16}, \mathrm{C}_{18}$ or more $\mathrm{C}_{n}$-fragment(s) with several methyl substituents. This linear polyketide unit is then cyclized by a biological intramolecular Diels-Alder cycloaddition to form the decalin scaffold. The second one is comprised of amino acids serine, threonine, leucine, phenylalanine, tyrosine or tryptophan-derived heterocyclic ring (pyrrolidine-2-one) joined to the decalin system. Typically, as a character of this family, this ring is tetramic acid that may also undergo a series of tautomeric shifts to form its derivatives, for example, having a reduced carbonyl carbon. Unfortunately, the exact 'timing' of $N$-methylation for this kind of compound remains unclear. These compounds have significant inhibitory activities against Gram-positive bacteria.

Equisetin (125), showing considerable biological activity in an array of assays and inhibiting HIV-1 integrase, ${ }^{96}$ was first isolated in 1974 from Fusarium equiseti by Burmeister et al. ${ }^{\mathbf{9 8 , 9 9}} \mathrm{It}$ comprises a substituted decalin system bearing a quaternary stereogenic center and an $N$-methylserine-derived heterocycle, tetramic acid. The proposed biosynthesis of $\mathbf{1 2 5}$ catalyzed by a PKS/NRPS hybrid is shown in Scheme $9 .^{100-102}$ The total synthesis has already been reported by the groups of Danishefsky, ${ }^{103}$ Shishido, ${ }^{104}$ and Dixon. ${ }^{105}$ More recently, Gao and coworkers reported synthetic studies of $\mathbf{1 2 5}$ and the biosynthetically related (+)-fusarisetin A based on the proposed biosynthetic hypothesis (Scheme 10). ${ }^{\mathbf{1 0 6}}$ A cyclization sequence involving an intermolecular Diels-Alder reaction followed by a Dieckmann cyclization yielded 125 (Scheme 11). Compound 125 and a new enantiomer, phomasetin (126), were isolated from Fusarium heterosporum and Phoma sp., respectively. ${ }^{\mathbf{1 0 7}}$ They are almost equally active in inhibiting recombinant integrase enzyme in vitro with $\mathrm{IC}_{50}$ values of $7-20 \mu \mathrm{M}$. Cryptocin (127), showing activity against a wide variety of plant pathogenic fungi (MIC of $0.78-1.56 \mu \mathrm{g} \mathrm{mL}^{-1}$ ) but not against human pathogenic fungi, was isolated from an endophytic fungus Cryptosporiopsis cf. quercina arising from the stems of Triptergyium wilfordii. ${ }^{108}$ Two endophytic Alternaria species produce another antibiotic called altersetin (128). ${ }^{109}$ It significantly inhibited several pathogenic Gram-positive bacteria with MIC values of no more than $1 \mu \mathrm{g} \mathrm{mL}{ }^{-1}$, but has no or much less effect on Gram-negative bacteria and pathogenic yeast. Similarly, Coniochaeta ellipsoidea produces a tetramic acid, coniosetin (129), with strong efficacy against Gram-positive bacteria and sensitive against resistant microbial pathogens, especially the multi-drug-resistant $S$. aureus at a concentration of $0.3 \mu \mathrm{g} \mathrm{mL}{ }^{-1} \cdot{ }^{110}$ From the coculture of T. harzianum and Catharanthus roseus, an equisetin derivative without the $N$-methyl, named trichosetin (130), was isolated. ${ }^{111}$ Interestingly, this compound was not detected in the individual cultures. Cissetin (131) with a cis-decalin ring fusion exhibited similar antibiotic activities as those of compounds 125 and 130 containing a different trans-decalin system, suggesting the possible biological function of tetramic acid. ${ }^{\mathbf{1 1 2}}$ Ophiosetin (132) was isolated from the mycopathogenic fungus Elaphocordyceps ophioglossoides. ${ }^{\mathbf{1 1 3}}$ Co-culture of the fungus Fusarium pallidoroseum with the bacterium Saccharopolyspora erythraea afforded $N$-demethylophiosetin (133) and pallidorosetins A and B $(\mathbf{1 3 4}, \mathbf{1 3 5})$, along with compounds 125 and 132. ${ }^{114}$ Compound 125 exhibited a $\mathrm{GI}_{50}$ of $144 \mathrm{nM}$ against the leukemia cell line CCRF-CEM. Following a histone deacetylase (HDAC)-based yeast screening method, streptosetin A (136) was purified and found to show weak inhibitory activity against yeast Sir2p and human SIRT1 and SIRT2. ${ }^{115}$ The structure of compound $\mathbf{1 3 6}$ was confirmed by X-ray crystal structure analysis and CD theoretical calculation. In an antibiotic screening program, methiosetin (137) was discovered as a modest antibacterial agent against $S$. aureus and Haemophilus influenzae. ${ }^{\mathbf{1 1 6}}$ CJ-17,572 (138) and CJ-21,058 (139) were isolated from Pezicula 


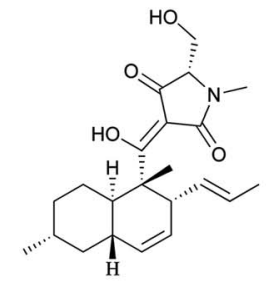

125<smiles>C/C=C/C=C/[C@H]1C(C)=C[C@H]2C[C@@H](C)CC[C@H]2[C@]1(C)/C(O)=C1/C(=O)NC(C(C)O)C1=O</smiles>

129<smiles>CC[C@H]1CC(=O)[C@]2(C)[C@@H](O)C(C)=CC[C@H]2[C@]1(C)C(=O)C1=C(O)NCC1=O</smiles>

136<smiles>[R20]C1(C)C=C(C(=O)[C@H]2[C@@H](/C(C)=C/C)C(C)=C[C@H]3C[C@H](C)C[C@H](C)[C@H]32)C(=O)N1</smiles>

$140 \mathrm{R}=\mathrm{CH}_{2} \mathrm{CH}_{2} \mathrm{CH}_{2} \mathrm{CH}_{3}$ $141 \mathrm{R}=\mathrm{Me}$

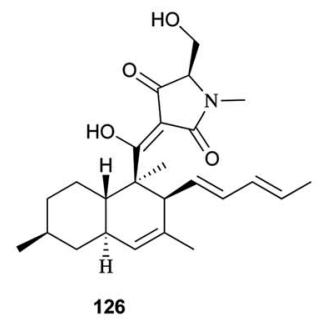

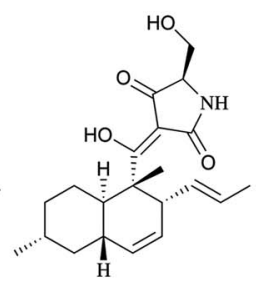

130<smiles>CC(O)C1C(O)=C(C(=O)[C@H]2[C@@H](C)C=C[C@H]3CCCC[C@@H]32)C(=O)N1C</smiles>

137

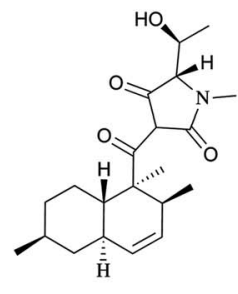

127

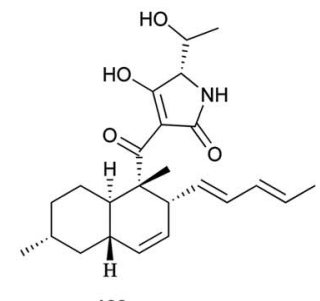

128

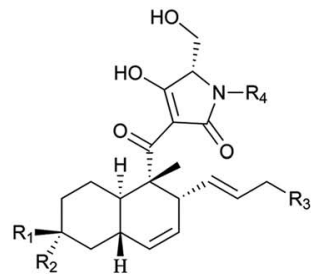

$132 \mathrm{R}_{1}=\mathrm{H}, \mathrm{R}_{2}=\mathrm{CH}_{2} \mathrm{OH}, \mathrm{R}_{3}=\mathrm{H}, \mathrm{R}_{4}=\mathrm{Me}$ $133 \mathrm{R}_{1}=\mathrm{H}, \mathrm{R}_{2}=\mathrm{CH}_{2} \mathrm{OH}, \mathrm{R}_{3}=\mathrm{H}, \mathrm{R}_{4}=\mathrm{H}$ $134 \mathrm{R}_{1}=\mathrm{OH}, \mathrm{R}_{2}=\mathrm{Me}, \mathrm{R}_{3}=\mathrm{H}, \mathrm{R}_{4}=\mathrm{Me}$ $135 \mathrm{R}_{1}=\mathrm{H}, \mathrm{R}_{2}=\mathrm{CH}_{2} \mathrm{OH}, \mathrm{R}_{3}=\mathrm{OH}, \mathrm{R}_{4}=\mathrm{Me}$<smiles>CC1CCC2C(C)C=CC(C)C2(C)C(C(=O)C2=C(O)C(C(C)O)N(C)C2=O)C1</smiles>

138
139

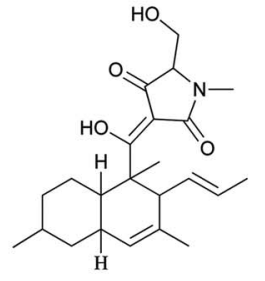

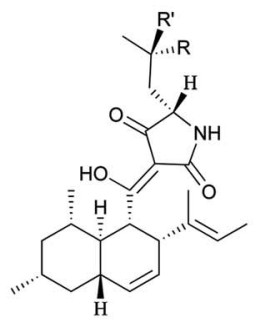

$144 \mathrm{R}=\mathrm{COOH}, \mathrm{R}^{\prime}=\mathrm{OH}$ $145 \mathrm{R}=\mathrm{OH}, \mathrm{R}^{\prime}=\mathrm{COOH}$<smiles>CC1=CC2CC(C)CCC2(C(=O)C2=C(O)CNC2=O)C(C)C1CC(C)OC1CCC(N)C(C)O1</smiles>

142<smiles>CCC(O)C(C)/C=C/C=C/C(O)CC1C=CC2CC(C)CC(C)C2C1(C)C(=O)C1=C(O)C(O)NC1=O</smiles>

143

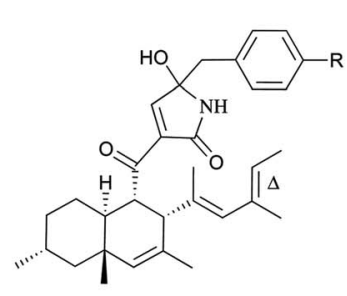

$151 \mathrm{R}=\mathrm{H}$ $152 \mathrm{R}=\mathrm{OH}, \Delta$ saturated

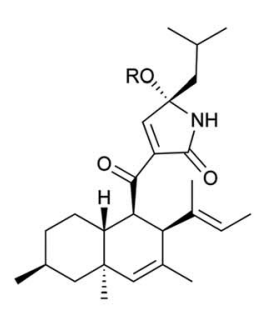

$146 \mathrm{R}=\mathrm{H}$ $148 \mathrm{R}=\mathrm{Me}$

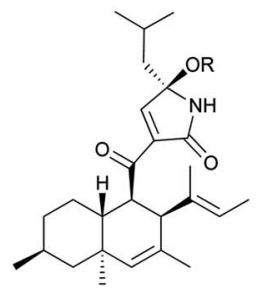

$147 \mathrm{R}=\mathrm{H}$ $149 \mathrm{R}=\mathrm{Me}$

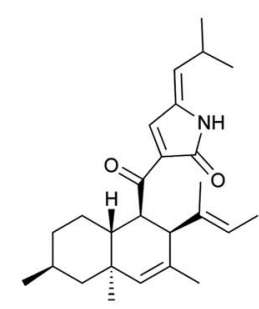

150<smiles>C/C=C(\C)[C@H]1C(C)=C[C@]2(C)C[C@@H](C)C[C@H](C)[C@H]2[C@H]1C(=O)C1=CC(O)(Cc2c[nH]c3ccccc23)NC1=O</smiles>

153

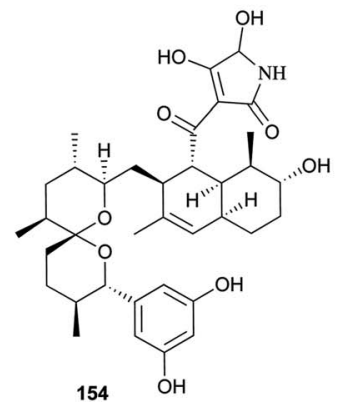

154 


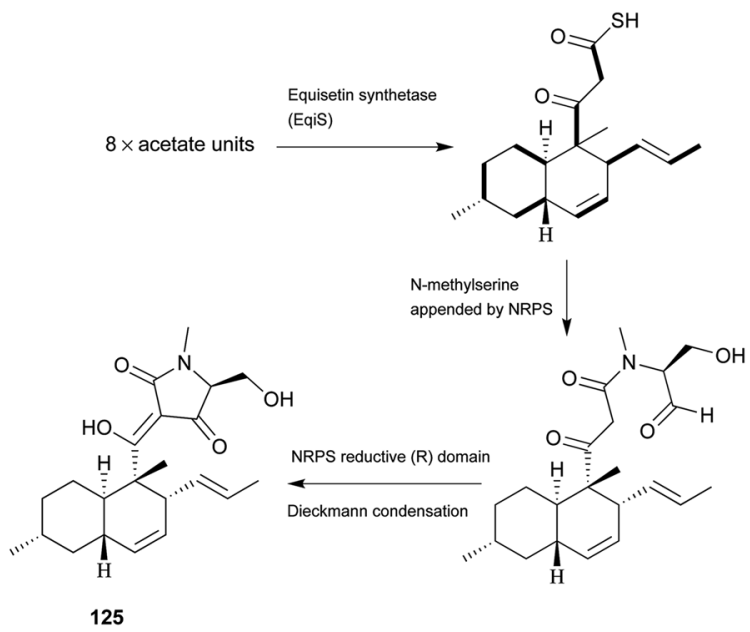

Scheme 9 The biosynthetic origin of 125. Bold bonds in the polyketide portion represent ${ }^{13} \mathrm{C}$-labelled acetate units. The timing of $\mathrm{N}$ methylation is unclear.

sp. and an unidentified fungus, respectively. ${ }^{117,118}$ Two structurally unusual tetramic acids, ascosalipyrrolidinones A (140) and B (141), were obtained from an endophytic fungus, Ascochyta salicorniae isolated from the green alga Ulva sp. ${ }^{119}$ The antimicrobial, anti-algal, nematicidal, antiplasmodial, anti-trypanosomal and cytotoxic properties as well as brine shrimp lethality of 141 were assessed. BU-4514N (142) with significant NGF-mimic activity and antibacterial efficacy against Grampositive bacteria, and delaminomycin A (143), a novel extracellular matrix receptor antagonist, have been isolated from the fermentation broth of Microtetraspora $\mathrm{sp} .{ }^{\mathbf{1 2 0}}$ and Streptomyces albulus, ${ }^{\mathbf{1 2 1}}$ respectively. Sch 210971 (144) and its epimer, Sch 210972 (145), showed potent inhibitory activity ( $\mathrm{IC}_{50}$ of $1.2 \mu \mathrm{M}$ and $79 \mathrm{nM}$, respectively) in the chemokine receptor CCR-5 in vitro binding assay, indicating an interesting structure-activity relationship of the relative configuration at tetramic acid. ${ }^{\mathbf{1 2 2}}$ Myceliothermophins A-E (146-150) (Fig. 5) (see Supporting Information of ref. 123) are the decalin polyketides containing tetramic acid moieties which were isolated from a fungus Myceliophthora thermophila. ${ }^{\mathbf{1 2 3}}$ Only compounds 146, 148, and 150 exhibited inhibitions against four cancer cell lines, A549, Hep3B, MCF-7, and HepG2, indicating the importance of the relative configuration of tetramic acids. Oteromycin $(\mathbf{1 5 1})^{\mathbf{1 2 4}}$ and ZG-1494 $\alpha$ (152), ${ }^{125}$ two phenylalanine-derived tetramic

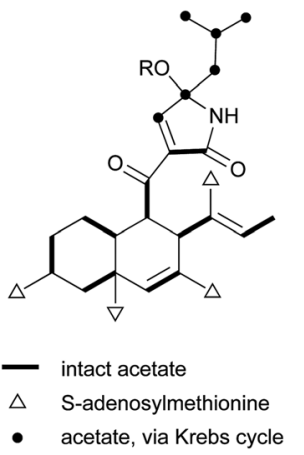

Fig. 5 Biosynthetic origin of myceliothermophins A-D (146-149).<smiles>C/C=C/C=C/C=C/C[C@H](C)CC/C=C(\C)C(=O)CC(=O)C#[SH]</smiles>

(S)-serine unsaturated fatty acid

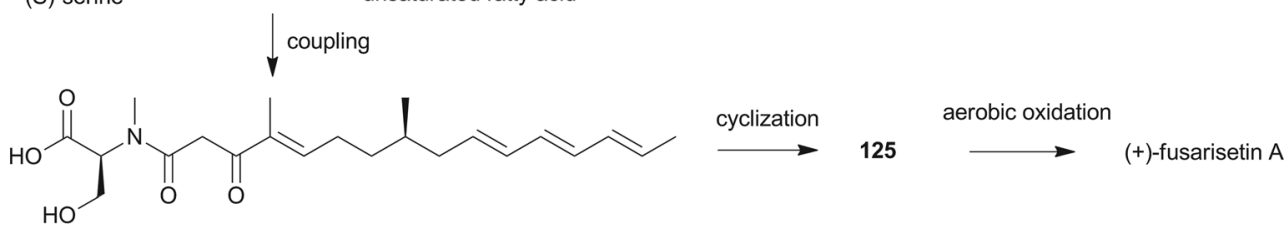
polyenoylamino acid

Scheme 10 Biosynthetic hypothesis for the total syntheses of 125 and (+)-fusarisetin A.

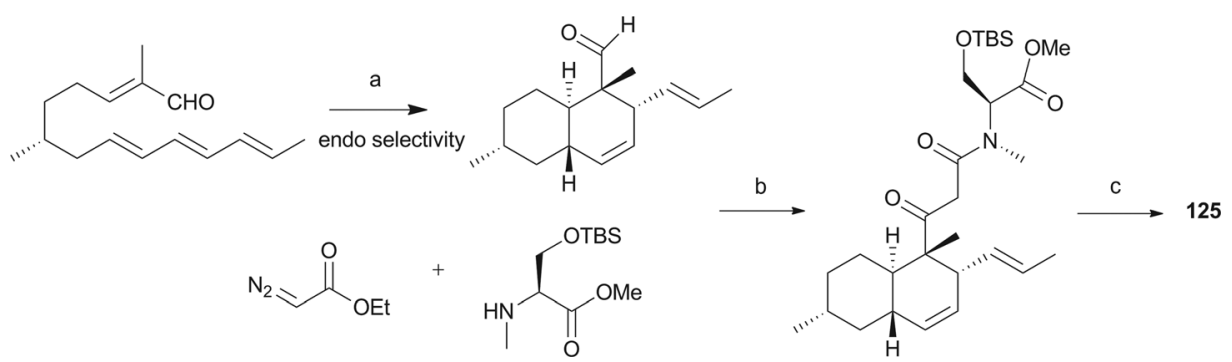

Scheme 11 Key construction of decalin ring system and the preparation of 125 . (a) $\mathrm{BF}_{3} \cdot \mathrm{Et}_{2} \mathrm{O},-78{ }^{\circ} \mathrm{C}, \mathrm{CH}_{2} \mathrm{Cl}_{2}, 20 \mathrm{~min}$; (b) $0{ }^{\circ} \mathrm{C}, 1.5 \mathrm{~h}$; then $(\mathrm{S})-$ serine derivative, DMAP, toluene, $118{ }^{\circ} \mathrm{C}, 18 \mathrm{~h}$; (c) $\mathrm{NaOMe}, \mathrm{MeOH}, 25^{\circ} \mathrm{C}, 2 \mathrm{~h}, 72 \%$, d.r. = 3 : 1 (at C3); then HF, $\mathrm{CH}_{3} \mathrm{CN}, 25{ }^{\circ} \mathrm{C}, 2 \mathrm{~h}, 95 \%$. 


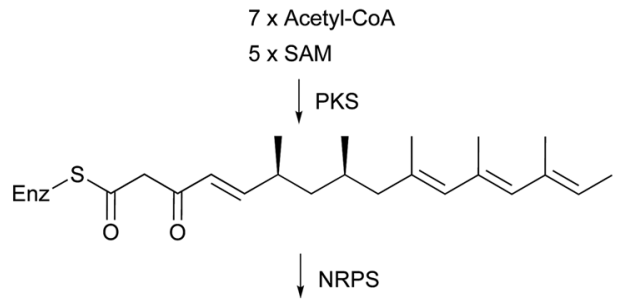<smiles>[R]C1(O)C=C(C(=O)/C=C/C(C)CC(C)C/C(C)=C/C(C)=C/C(C)=C/C)C(=O)N1</smiles><smiles>[R]C1(O)C=C(C(=O)/C=C\C(C)CC(C)C/C(C)=C/C(C)=C/C(C)=C/C)C(=O)N1</smiles>

$\triangle \mathrm{L}$-[S- $\left.{ }^{13} \mathrm{CH}_{3}\right]$ methionine $\mathrm{CH}_{3}-{ }^{13} \mathrm{COOH}$

Scheme 12 Proposed biosynthesis of 153 and the labeling patterns observed in feeding experiments.

acids, were isolated from an unidentified fungus and Penicillium rubrum, respectively. Compound $\mathbf{1 5 1}$ was reported to be a novel antagonist of endothelin receptor while 152 was an inhibitor of platelet-activating factor acetyltransferase. An endophytic fungus, Codinaeopsis gonytrichoides, produced an antimalarial compound that is active against Plasmodium falciparum with an $\mathrm{IC}_{50}$ of $4.7 \mu \mathrm{M} .{ }^{126}$ This metabolite, with its unusual heterocyclic unit linking indole and decalin fragments, was named codinaeopsin (153) and was proposed to be biosynthesized by the PKS-NRPS hybrid involving an IMDA-like addition (Scheme 12). ${ }^{126} \mathrm{~A}$ hexacyclic secondary metabolite, integramycin (154) isolated from Actinoplanes sp., exhibited an $\mathrm{IC}_{50}$ value of $4 \mu \mathrm{M}$ against HIV-1 integrase. ${ }^{127}$

Lydicamycin (155) with a long side chain proved to be a potent antibiotic against Gram-positive bacteria such as $B$. subtilis and S. aureus with MIC values of 1.5 and $6.2 \mu \mathrm{g} \mathrm{mL}^{-1}$, respectively. ${ }^{128,129}$ It was isolated from the culture broth of an actinomycete, Streptomyces lydicus. From another actinomycete, Streptomyces platensis, four novel congeners, TPU-0037A-D (156-159), were obtained. ${ }^{130}$ They also exhibited inhibition of some Gram-positive bacteria with MIC values of 1.56$12.5 \mu \mathrm{g} \mathrm{mL}^{-1}$.

Recently, three novel broad-spectrum antibiotics (160-162) active against Gram-positive bacteria by inhibiting DNA gyrase and bacterial topoisomerase IV were reported. ${ }^{131-133}$ They consist of a trans-decalin, tetramic acid, two unusual sugars, and dichloropyrrole carboxylic acid. Kibdelomycin (160) and its demethylated congener kibdelomycin A (161) were isolated from a previously undescribed strain of Kibdelosporangium by Singh and co-workers. ${ }^{131}$ Compound 160 also demonstrated potent and selective activity against toxigenic Clostridium difficile. ${ }^{132}$ Amycolamicin (162) (AMM) was obtained from the culture broth of the soil actinomycete, Amycolatopsis sp. ${ }^{133}$

\subsection{4-Hydroxy-2-pyridone alkaloids}

4-Hydroxy-2-pyridone alkaloids have attracted much attention in the scientific community owing to their diverse biological activities. ${ }^{134}$ A review focusing only on their structures and synthetic approaches has been published. ${ }^{134}$ Here, we mainly pay attention to the biological activities and biosynthesis of

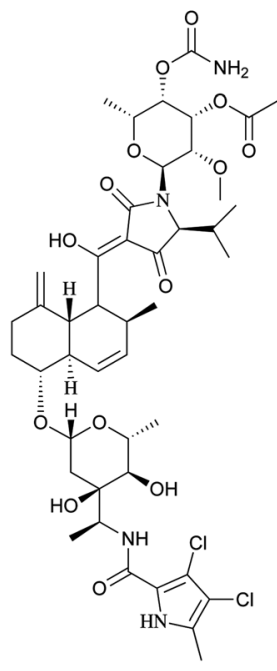

160

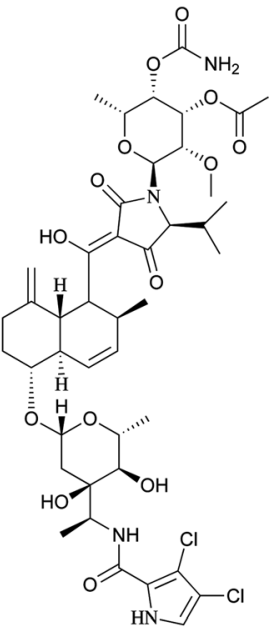

161

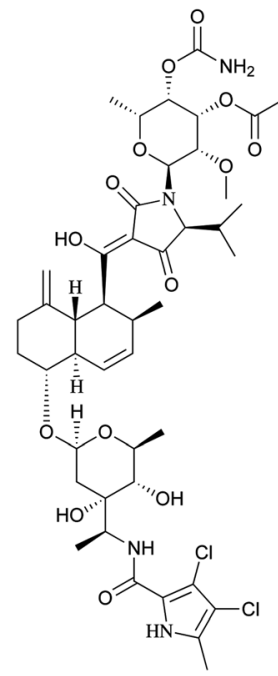

162

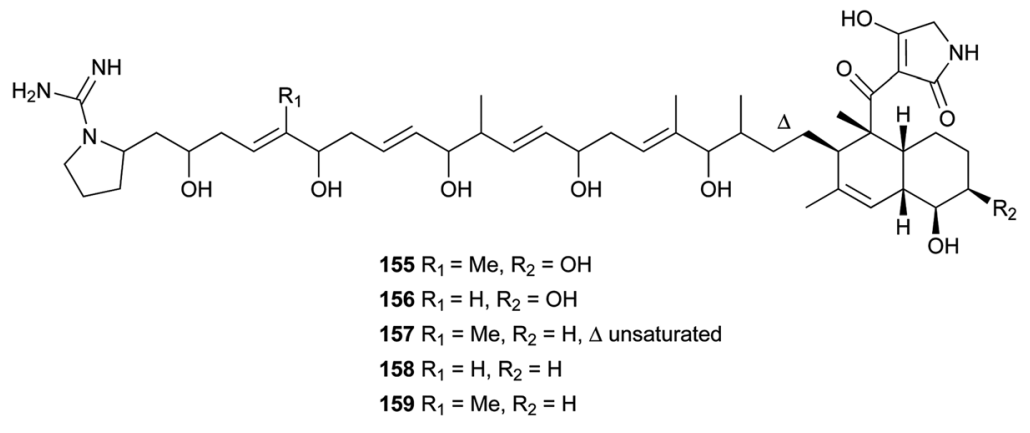


4-hydroxy-2-pyridone alkaloids with a decalin scaffold, and include some recent discoveries. Their biosynthesis is related to that of polyketide tetramic acid, phenylalanine-derived heterocyclic ring (vide supra, Section 3.8). In their biosynthesis, the key rearrangement of the tetramic acid ring eventually results in the construction of the 4-hydroxy-2-pyridone.

Chemical investigation of an EtOAc extract from the coprophilous fungus Apiospora montagnei led to the isolation of an antifungal metabolite named apiosporamide (163). ${ }^{\mathbf{1 3 5}}$ Fischerin (164) was isolated from an ascomycete, Neosartorya fischeri. It was toxic to mice, causing lethal peritonitis. ${ }^{136}$ The biogenetic pathway of $\mathbf{1 6 4}$ related to tetramic acid has been studied (Scheme 13). This kind of biosynthesis related to tetramic acid derivatives was also supported by the group of Hertweck in their discovery of a silent PKS-NRPS hybrid gene cluster and the resulting new pyridine metabolites. ${ }^{\mathbf{1 3 7}} \mathrm{YM}$ 215343 (165), isolated from Phoma sp., showed antifungal activities against the pathogenic fungi $C$. albicans, Cryptococcus neoformans, and Aspergillus fumigatus (MIC values of 2-16 $\mu \mathrm{g}$ $\mathrm{mL}^{-1}$ ) and was cytotoxic against HeLa S3 cells ( $\mathrm{IC}_{50}$ of $3.4 \mu \mathrm{g}$ $\left.\mathrm{mL}^{-1}\right) .{ }^{138}$ An insect-associated fungus tentatively identified as Cytospora, was found to produce a cholesteryl ester transfer protein inhibitor $166\left(\mathrm{IC}_{50}\right.$ of $\left.40 \mu \mathrm{M}\right) \cdot{ }^{139}$ More recently, four new members of this family, didymellamides A-D (167-170) were isolated from the marine-derived fungus Stagonosporopsis cucurbitacearum growing on the surface of an unidentified sponge. ${ }^{\mathbf{1 4 0}}$ Compound 167 showed antifungal activity against

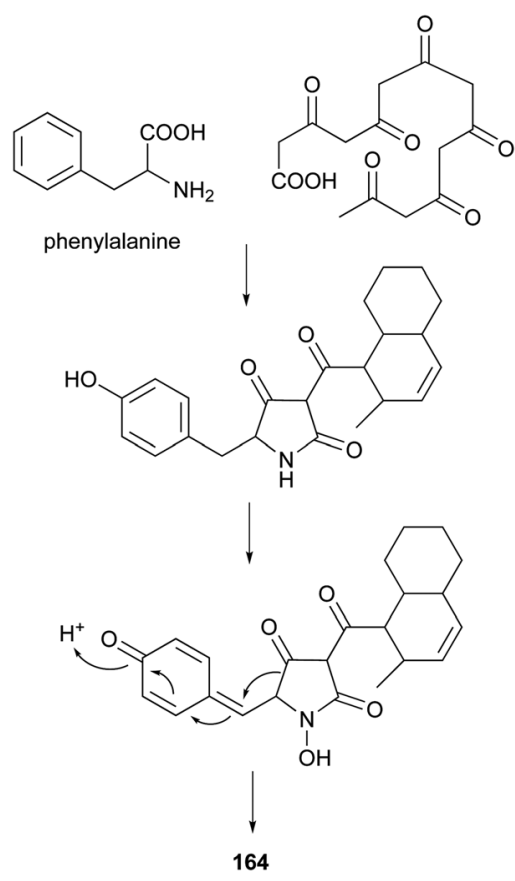

Scheme 13 The proposed biogenesis of 164 .<smiles>C[C@H]1CC[C@@H]2[C@@H](C=C[C@@H](C)[C@@H]2C(=O)c2c(O)c([C@]3(O)CC[C@@H](O)[C@H]4O[C@@H]43)c[nH]c2=O)C1</smiles>

163<smiles></smiles>

167<smiles>C[C@H]1C=C[C@H]2CCCC[C@H]2[C@H]1C(=O)c1c(O)c(C2(O)CCC(O)C3OC32)cn(O)c1=O</smiles>

164<smiles>CC1CC[C@H]2C(C(=O)c3c(O)c(-c4ccc(O)cc4)c[nH]c3=O)C(C)C=C[C@H]2C1</smiles>

168<smiles>[X]C1CCC(O)(c2cn([R])c(=O)c(C(=O)[C@H]3[C@@H](C)C=C[C@H]4C[C@H](C)CC[C@H]43)c2O)[C@H]2O[C@H]12</smiles>

$165 \mathrm{R}=\mathrm{H}, \mathrm{X}=\mathrm{O}$

$166 \mathrm{R}=\mathrm{OH}, \mathrm{X}=\mathrm{OH}, \mathrm{H}$<smiles>[R]C1=CC(=O)CCC1(O)c1c[nH]c(=O)c(C(=O)[C@H]2[C@@H](C)C=C[C@H]3C[C@H](C)CC[C@]23C)c1O</smiles>

$169 \mathrm{R}=\mathrm{H}$

$170 \mathrm{R}=\mathrm{OH}, \Delta$ saturated<smiles>[R]c1ccc(-c2c[nH]c(=O)c(C(=O)[C@H]3C=C(C)[C@H]4CC([R])[C@H]([R])[C@@H]([Y])C[C@H]4[C@@H]3/C=C/C)c2O)cc1[R]</smiles>

$171 \mathrm{R}_{1}=\mathrm{Me}, \mathrm{R}_{2}=\mathrm{H}, \mathrm{R}_{3}=\mathrm{H}, \mathrm{R}_{4}=\mathrm{OH}$

$172 \mathrm{R}_{1}=\mathrm{CH}_{2} \mathrm{OH}, \mathrm{R}_{2}=\mathrm{H}, \mathrm{R}_{3}=\mathrm{H}, \mathrm{R}_{4}=\mathrm{OH}$

$173 \mathrm{R}_{1}=\mathrm{COOH}, \mathrm{R}_{2}=\mathrm{H}, \mathrm{R}_{3}=\mathrm{H}, \mathrm{R}_{4}=\mathrm{OH}$

$174 \mathrm{R}_{1}=\mathrm{CH}_{2} \mathrm{OAC}, \mathrm{R}_{2}=\mathrm{H}, \mathrm{R}_{3}=\mathrm{H}, \mathrm{R}_{4}=\mathrm{OH}$

$175 \mathrm{R}_{1}=\mathrm{CH}_{2} \mathrm{OH}, \mathrm{R}_{2}=\mathrm{OH}, \mathrm{R}_{3}=\mathrm{H}, \mathrm{R}_{4}=\mathrm{OH}$

$176 \mathrm{R}_{1}=\mathrm{CH}_{2} \mathrm{OAc}, \mathrm{R}_{2}=\mathrm{OH}, \mathrm{R}_{3}=\mathrm{H}, \mathrm{R}_{4}=\mathrm{OH}$

$177 \mathrm{R}_{1}=\mathrm{CH}_{2} \mathrm{OH}, \mathrm{R}_{2}=\mathrm{H}, \mathrm{R}_{3}=\mathrm{OH}, \mathrm{R}_{4}=\mathrm{OH}$

$178 \mathrm{R}_{1}=\mathrm{CH}_{2} \mathrm{OH}, \mathrm{R}_{2}=\mathrm{OX}, \mathrm{R}_{3}=\mathrm{H}, \mathrm{R}_{4}=\mathrm{OH}$

$179 R_{1}=M e, R_{2}=H, R_{3}=H, R_{4}=X$ 
azole-resistant C. albicans with an MIC value of $3.1 \mu \mathrm{g} \mathrm{mL} \mathrm{m}^{-1} .^{140}$ The antifungal antibiotic, ilicicolin $\mathrm{H}$ (171), was first isolated in 1971 from the imperfect fungus Cylindrocladium ilicicola harboring the dead leaf of beech (Fagus sp.). ${ }^{\mathbf{1 4 1}}$ It was found to inhibit the yeast cytochrome $b_{1}$ complex by interacting with the Qn site of the complex. ${ }^{\mathbf{1 4 2}}$ Using feeding experiments conducted with different labeled acetates and phenylalanine, biosynthesis of $\mathbf{1 7 1}$ was investigated and found to be similar to 164. ${ }^{143}$ Singh et al. worked on the biotransformation of compound 171 using Actinoplanes sp. and Streptomyces sp., and found eight new oxidized products $172-179 .^{144}$ The predominant modification was selective oxidation of the methyl group on the decalin ring. Only compound $\mathbf{1 7 1}$ had significant antifungal activity against $C$. albicans with an MIC value of $8 \mathrm{ng}$ $\mathrm{mL}^{-1}$. The total syntheses of compounds 163, 165, and 171 have been summarized in a recent review. ${ }^{\mathbf{1 3 4}}$

\subsection{Spirotetronates}

Spirotetronates, the macrolide natural products consist of a trans-decalin system, a spiro ring between a cyclohexene and a tetronic acid, several similar or dissimilar deoxysugars and/or a multi-substituted benzene or pyrrole.

Chlorothricin (180), the first reported member of spirotetronate family, was isolated from an actinomycete Streptomyces antibioticus in 1969 by Keller-Schierlein et al. ${ }^{\mathbf{1 4 5}}$ Tetrocarcin A (181) was isolated in 1979 from the bacterium Micromonospora chalcea by Tomita et al. ${ }^{\mathbf{1 4 6}}$ and was found to be identical to antlermicin A (also isolated from $M$. chalcea). ${ }^{\mathbf{1 4 7}}$ Waitz et al. isolated kijanimicin (182) (or Sch 25663) in 1981 from a complex of antibiotics produced by a previously undescribed species of Actinomadura, A. kijaniata. ${ }^{148}$ Its structure was investigated and confirmed by Mallams et al. in the same year. ${ }^{\mathbf{1 4 9 , 1 5 0}}$

Compounds 180-182 are well-known members of more than 60 spirotetronate-type compounds, and exhibit antibacterial activities against Gram-positive bacteria and show selective antitumor activities. ${ }^{151}$ Other biological activities are increasingly being revealed. Compound $\mathbf{1 8 0}$ has been shown to inhibit the biosynthesis of cholesterol from mevalonate with an $\mathrm{IC}_{50}$ value of 0.1 $\mathrm{mM},{ }^{152}$ and further inhibited pyruvate carboxylases purified from vertebrate sources not owing to the occupancy of the acyl-CoA site. ${ }^{\mathbf{1 5 3}}$ Metabolite $\mathbf{1 8 1}$ has been proven to be an efficient inducer of apoptosis, ${ }^{154}$ showing selective inhibition against the mitochondrial functions of Bcl-2 to suppress its anti-apoptotic function in Bcl-2-overexpressing cells, ${ }^{155}$ mediating apoptosis via endoplasmic reticulum stress preferentially in B-chronic lymphocytic leukemia cells, ${ }^{156}$ and inactivating the PI3-kinase pathway to directly induce apoptosis of human breast cancer cells. ${ }^{157}$

The biosynthetic gene clusters for compounds 180-182 were reported in 2006, ${ }^{158} 2008,{ }^{159}$ and $2007,{ }^{151}$ respectively. During the same period, the proposed biosynthetic pathways for the representative 180 (Scheme 14), 181, and 182 were also reported. It is notable that their biosynthesis involves two $[4+2]$ Diels-Alder cycloadditions resulting in the formation of the trans-decalin and the spiro-fusion ring systems. However, it is still unclear whether these two Diels-Alder reactions are performed enzymatically or non-enzymatically. The above results indicate the common biosynthetic route for spirotetronate antibiotics to include: (1) formation of the polyketide linear chain; (2) incorporation of a glycerol-derived three-carbon unit; $^{160,161}(3)$ involvement of two [4 +2$]$ Diels-Alder cycloadditions resulting from either enzymatic or non-enzymatic processes; and (4) modification of the aglycone cores by some moieties, such as various deoxysugars.

To the best of our knowledge, total syntheses of compounds 180-182 have not yet been reported, even though many syntheses for their aglycones have been achieved and many preparations of the functional intermediates have been accomplished. ${ }^{\mathbf{1 6 2 - 1 6 8}}$ Enantioselective synthesis of (-)-chlorothricolide, the aglycone of 180, was achieved in 1994 by Roush and Sciotti (Scheme 15). ${ }^{\mathbf{1 6 2 , 1 6 3}}$ Prior to this work, the group of Yoshii reported the chemical synthesis of racemic

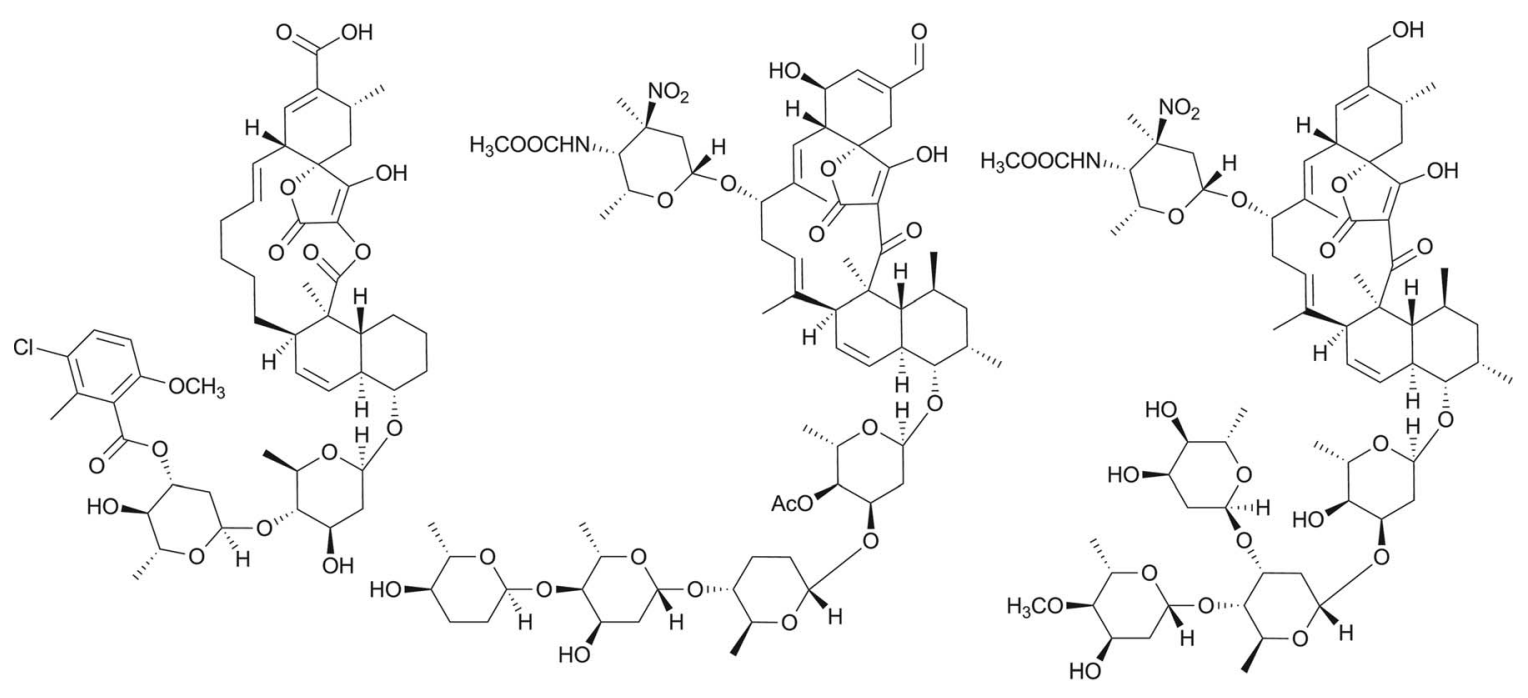


A)

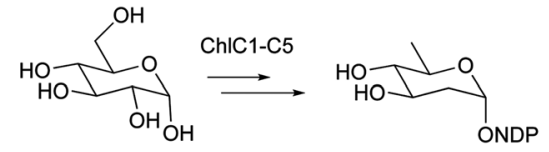

Glycolytic pathway ChID1-D3 intermediate<smiles>C=C(O)C(=O)OC#CC(=O)O</smiles>

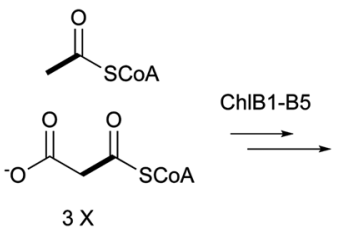<smiles>COc1ccc(Cl)c(C)c1C(=O)SCCN</smiles>

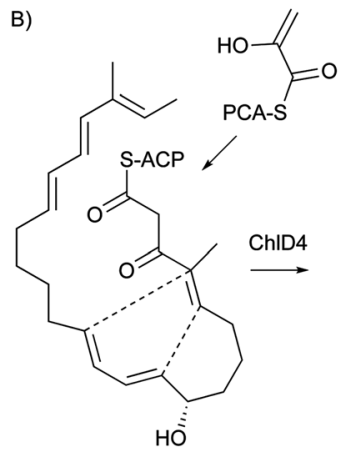

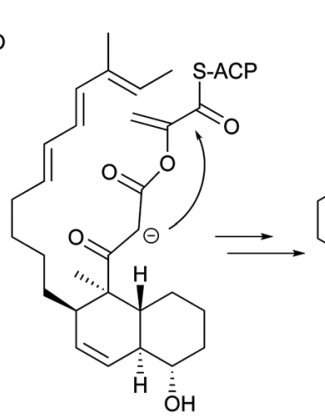

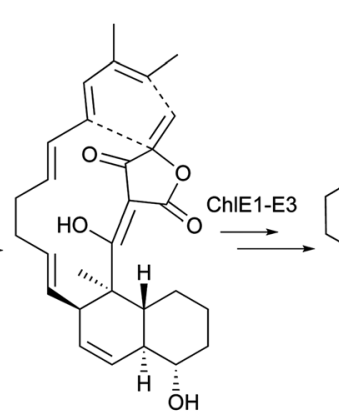

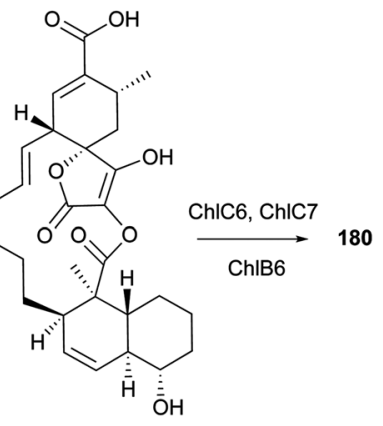

chlorothricolide

Scheme 14 Biosynthetic study on spirotetronate antibiotics. (A) Proposed biosynthesis for deoxysugar olivose, 3-carbon unit enoylpyruvate, and 2-methoxy-5-chloro-6-methylsalicyclic acid. (B) Proposed two [4 + 2] IMDA cycloadditions in the biosynthesis of 180<smiles>C=CCOC(=O)/C(C)=C/CCC[C@@H](/C=C(\C=C\CCCC/C=C/C=C/C(=C/C)CO[R16](=O)[O-])[SiH2]OC)OC</smiles>

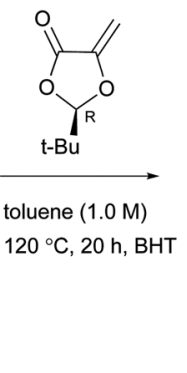

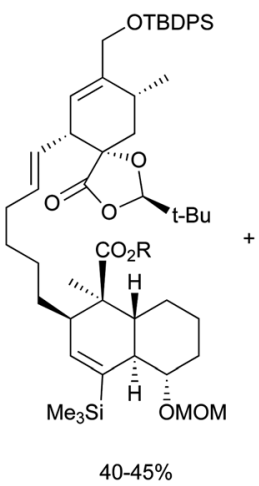

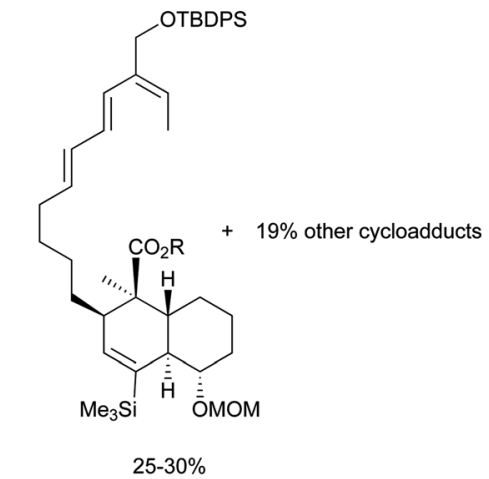

Scheme 15 Roush's key Diels-Alder reactions in the enantioselective total synthesis of (-)-chlorothricolide.

24-O-methylchlorothricolide (Scheme 16). ${ }^{164}$ Both syntheses involved Diels-Alder cyclizations to construct the spirotetronate structure and decalin motif of the aglycones. The aglycon of compound 181, tetronolide, was first synthesized by the group of Yoshii in 1991. ${ }^{\mathbf{1 6 5 , 1 6 6}}$ Two key steps, the aldol coupling of spirotetronate and a Diels-Alder product decalin system and the internal cyclization, were involved in the construction of the macro-ring as shown in Scheme $17 .{ }^{\mathbf{1 6 5 , 1 6 6}}$ A tandem ketenetrapping $[4+2]$ cycloaddition strategy for the total synthesis of (+)-tetronolide was also described. ${ }^{\mathbf{1 6 7}}$ The synthetic methods of the functional fragments of spirotetronates involving the intermolecular Diels-Alder reaction can be increasingly found in many reports. ${ }^{168,169}$

\subsection{Pyrrolizidines}

UCS1025-A (183) and -B (184), possessing the unprecedented furopyrrolizin-2,6-dione system, were isolated in 2000 from the broth of the fungus Acremonium sp. ${ }^{170}$ Their structural elucidations were achieved by spectral data and X-ray crystallographic analysis, ${ }^{171}$ indicating two more tautomeric isomers in UCS1025A. Compared with compound 184, 183 exhibited significant inhibitory activities against the Gram-positive bacteria S. aureus, B. subtilis and Enterococcus hirae, and Gramnegative bacterium Proteus vulgaris with the MIC values ranging from 1.3 to $5.2 \mu \mathrm{g} \mathrm{mL}{ }^{-1}$. Moreover, they possessed weak antiproliferative activities against human tumor cell lines ACHN, A431, MCF-7, and T24.

The total synthesis of compound 183 has been accomplished by four groups worldwide. ${ }^{2}$ The first synthesis of $\mathbf{1 8 3}$ was reported by Lambert and Danishefsky, ${ }^{172}$ who achieved asymmetric access to the furopyrrolizidine fragment and used a powerful enantioselective organocatalytic intramolecular Diels-Alder reaction to obtain the required decalin. ${ }^{82}$ The remarkable $\mathrm{BEt}_{3}$-mediated reaction allowed direct coupling of the furopyrrolizidine fragment and the 

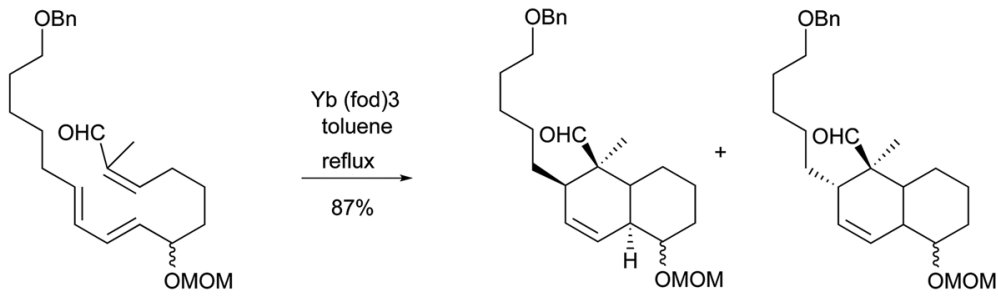

$2.3: 1$

24-O-Methylchlorothricolide
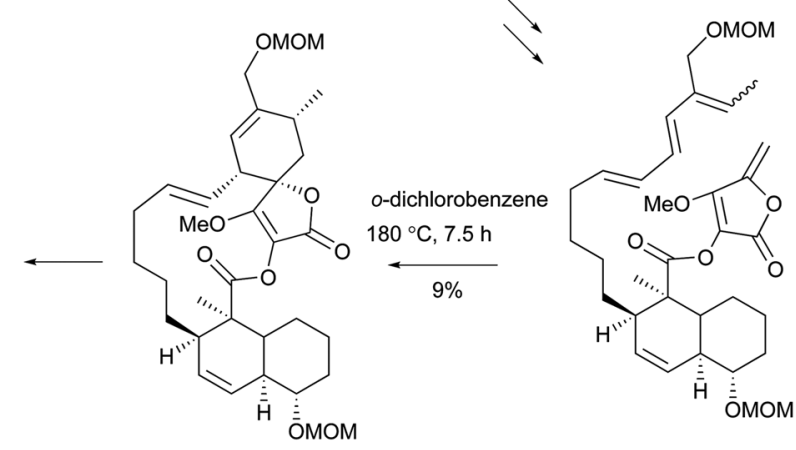

Scheme 16 Yoshii's IMDA approach to the synthesis of racemic 24-O-methylchlorothricolide.
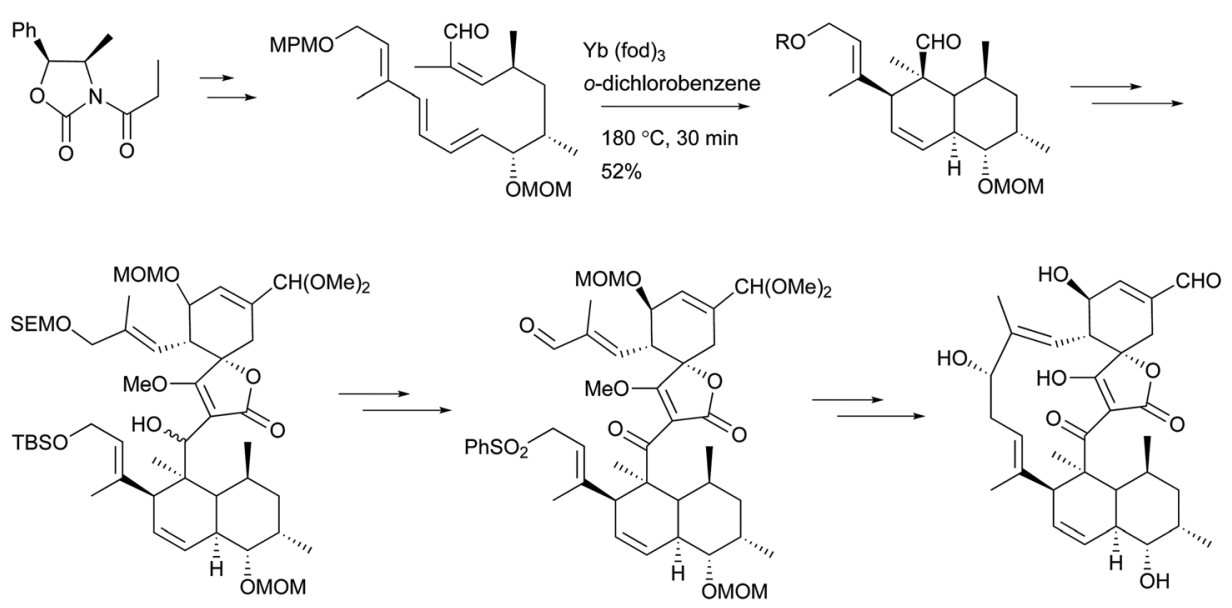

Scheme 17 Yoshii's synthesis of the aglycone of 181, tetronolide.

decalin aldehyde to provide the full skeleton of $\mathbf{1 8 3}$ (Scheme 18). ${ }^{172}$

A biomimetic total synthesis of $( \pm)$-UCS1025A involving seven linear steps was accomplished by Hoye et al.

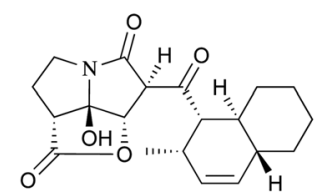

183

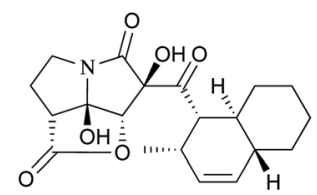

184

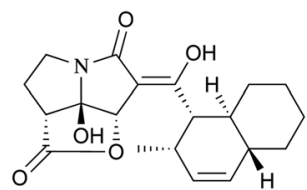

183-isomer-1

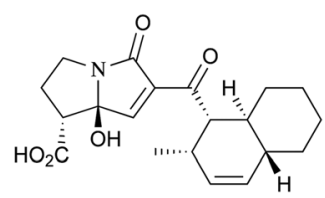

183-isomer-2
(Scheme 19). ${ }^{11}$ The interesting automatic cyclization of a long chain in phosphate buffer $\left(\mathrm{pH} 7.2, \mathrm{D}_{2} \mathrm{O}\right)$ to the decalin system indicated a possible non-enzymatic biosynthetic event in vivo. Furthermore, an effective trialkylsilyl triflate (TMSOTf)-mediated cyclization of ester-imide to pyrrolizidine was reported by Hoye et al. (Scheme 20). ${ }^{173}$

The group of Christmann synthesized a simplified analogue of compound 183 using an aldol coupling approach (Scheme 21). ${ }^{174}$ They performed an improved MacMillan organocatalytic Diels-Alder reaction to obtain the concise transdecalin moiety with an enantiomeric excess $(e e)$ of $99 \%$. For the pyrrolizidine fragment of compound 183, compared to Danishefsky's synthesis in nine steps, ${ }^{172}$ the group of Christmann showed its two-step enantioselective synthesis (Scheme 22). ${ }^{175}$ The conditions can also be applied to the commercially available maleimide and some substituted maleimidic acids. An enantioselective lactonization and the trituration enrichment at 
<smiles>O=C1OC2C(I)C(=O)N3CC[C@@H]1C23O</smiles><smiles>C[C@H]1C=C[C@]2(F)CCCC[C@H]2[C@@H]1C=O</smiles><smiles>O=C(O)[C@H]1C(=O)O[C@H]2C=C[C@@H]3CCCC[C@H]3[C@H]2C1O</smiles>

quantitative single diastereomer

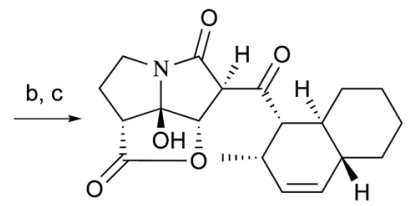

183
Scheme 18 Danishefsky's coupling protocol for the synthesis of 183 (a) $\mathrm{BEt}_{3}$, toluene, $-78{ }^{\circ} \mathrm{C}, \mathrm{P}=\mathrm{TBS}$; (b) TBAF, THF, $85 \%$; (c) Dess-Martin periodinane, $\mathrm{CH}_{2} \mathrm{Cl}_{2}, 84 \%$.
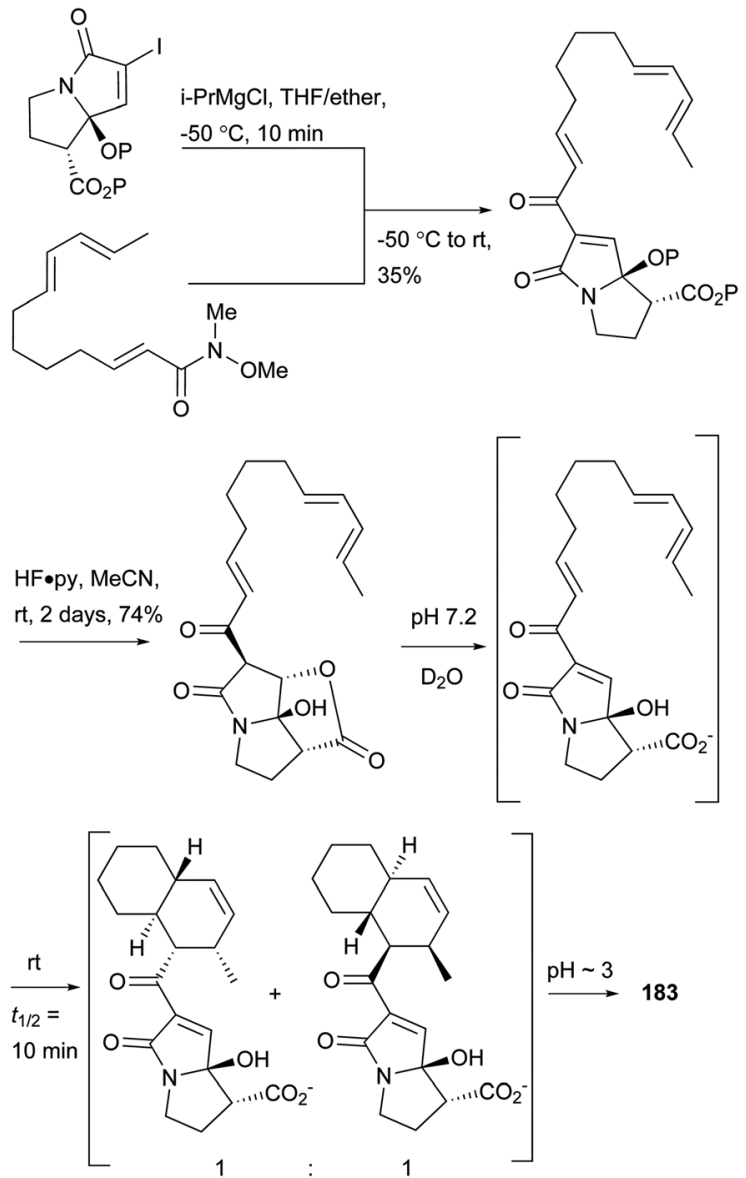

Scheme 19 Hoye's biomimetic total synthesis of 183.

a high eutectic $e e$ for the pyrrolizidine fragment were also reported.

A stereoselective total synthesis of compound $\mathbf{1 8 3}$ was performed by Kan and co-workers, involving an intramolecular Diels-Alder reaction to the decalin skeleton, an intramolecular Staudinger/aza-Wittig reaction to the eightmembered lactam, the stereoselective construction of a labile<smiles>O=C(O)CCCN1C(=O)C=CC1=O</smiles>

TMSOTf, TEA $\mathrm{DCM}, \mathrm{rt}$

dr $62: 1,88 \%$<smiles>COC1CCN2C(=O)C=CC12O</smiles>

Scheme 20 Hoye's silylative Dieckmann-like cyclization to pyrrolizidine fragment.

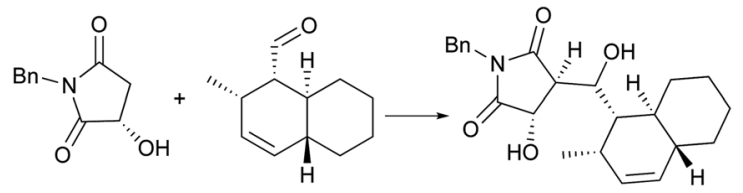

Scheme 21 Christmann's aldol coupling involved in the synthesis of an analogue of 183 . Condition: NaHMDS, THF, $0{ }^{\circ} \mathrm{C}$, then decalin substance, $-78{ }^{\circ} \mathrm{C}, 3.5 \mathrm{~h}, 55 \%$.

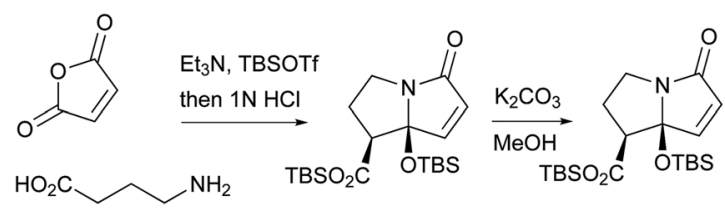

Scheme 22 Christmann's two-step synthesis of the pyrrolizidine fragment.

hemiaminal moiety to assess the pyrrolizidinone skeleton, and the condensation of decalin and the pyrrolizidinone system (Scheme 23). ${ }^{2}$

Two new pyrrolizidinone antibiotics closely related to $\mathbf{1 8 3}$ and 184, CJ-16,264 (185) and CJ-16,367 (186), were isolated from an unidentified soil fungus CL39457. ${ }^{176}$ Recently, a
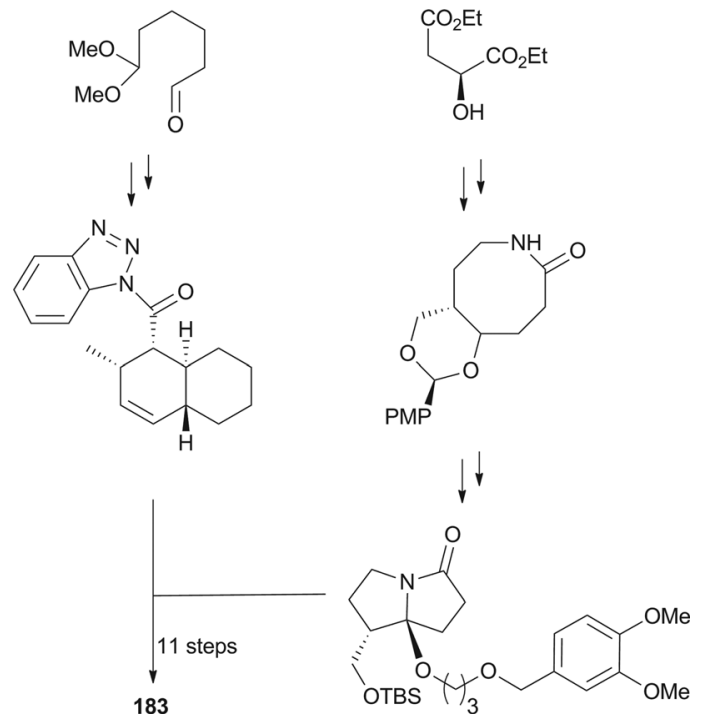

Scheme 23 Kan's stereo-controlled total synthetic method of 183 
novel proteasome inhibitor, pyrrolizilactone (187), was discovered from an uncharacterized fungus, ${ }^{177}$ and inhibited the trypsin-linked activity of the proteasome. ${ }^{178}$ All these pyrrolizidine antibiotics could be biogenetically related to tetramic acid derivatives. Specifically, apart from a common polyketide precursor and an amino acid (glycine) as suggested in tetramic acid biosynthesis, an unknown $\mathrm{C} 4$ unit could be involved in the construction of these pyrrolizidine antibiotics. ${ }^{171}$

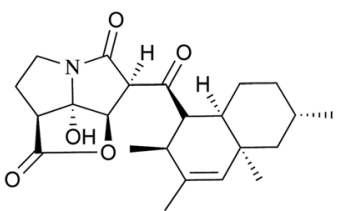

185

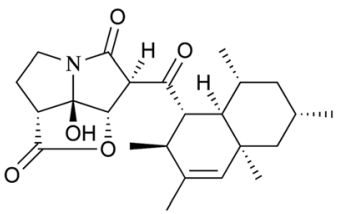

187

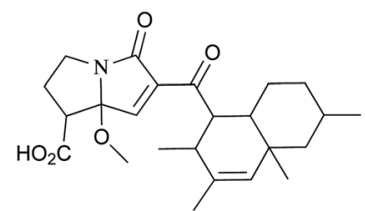

186

\subsection{Others}

Two unprecedented polycyclic polyketides, alchivemycins A (188) and B (189), were isolated from a plant-derived actinomycete Streptomyces sp. ${ }^{\mathbf{1 7 9 , 1 8 0}}$ Their structures were confirmed by X-ray crystal structure analysis along with chemical and spectroscopic methods. They showed a selective antimicrobial activity against Micrococcus luteus with MIC values of 0.03 and $0.004 \mu \mathrm{g} \mathrm{mL} \mathrm{mL}^{-1}$, respectively without inhibitory effects on $B$. subtilis, E. coli, or C. albicans. Furthermore, they exhibited potency in inhibiting murine colon carcinoma 26-L5 cell invasion ( $\mathrm{IC}_{50}$ of 0.34 and $1.9 \mu \mathrm{M}$, respectively) without showing any cytotoxic effects. The unprecedented heterocyclic ring system, $2 \mathrm{H}$-tetrahydro-4,6-dioxo-1,2-oxazine, was proposed to be biosynthesized via a similar PKS-NRPS pathway as that of tetramic acid. ${ }^{\mathbf{1 8 0}}$ This hypothesis was further investigated by feeding ${ }^{13} \mathrm{C}$-labeled precursors (Fig. 6). Apiosporic acid (190) is a polyketide-derived compound from a marine fungus A. montagnei isolated from the inner tissue of the North Sea alga Polysiphonia violacea.$^{181}$ Nahuoic acid A (191), the first known selective SAM-competitive inhibitor of SETD8 $\left(\mathrm{IC}_{50}\right.$ of $6.5 \pm 0.5 \mu \mathrm{M})$, was produced by a Streptomyces sp. isolated from a tropical marine sediment. ${ }^{\mathbf{1 8 2}}$ The actinomycete Kitasatospora griseola was known to produce two unprecedented glucosylated polyketides, satosporins A 192 and B 193. ${ }^{183}$ Their absolute configurations were confirmed using TDDFT/CD calculations and chemical derivatization methods. Two novel antimicrobial agents, tetrodecamycin (194) and dihydrotetrodecamycin (195) were obtained from the broth of Streptomyces nashvillensis. ${ }^{\mathbf{1 8 4}}$

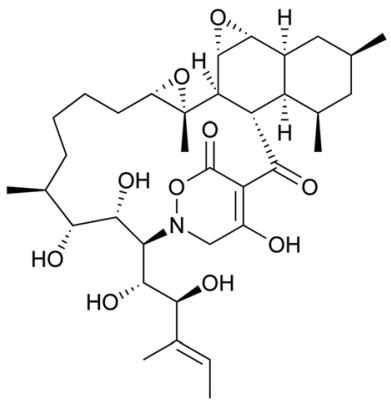

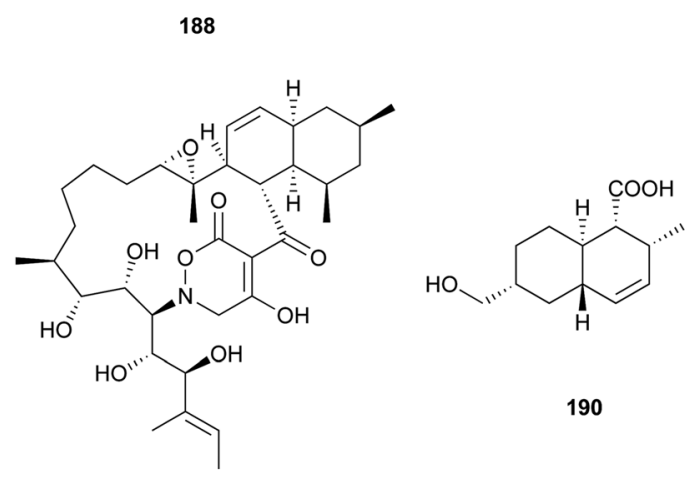

189

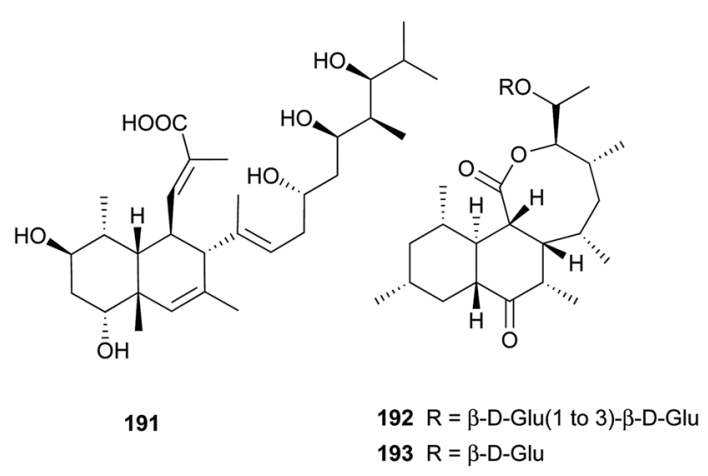

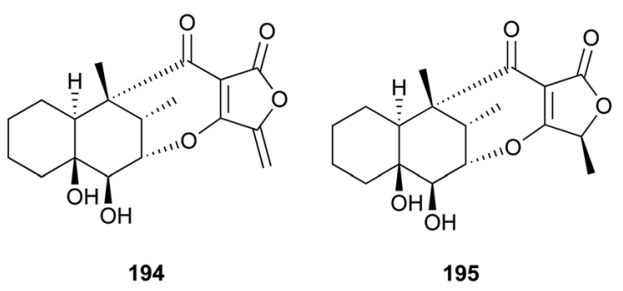

\section{Isoprenoid decalin}

The isolation and structures of natural sesquiterpenoids, diterpenoids, or marine natural products containing isoprenoid-derived decalin have been covered in a series of reports. ${ }^{4-6}$ Therefore, in this manuscript, we only highlight the important features of isoprenoid-derived decalin secondary metabolites isolated from microorganisms (mainly fungi). Almost always, these isoprenoid decalinderived compounds of microbial origin belong to sesquiterpenes mainly including cadinane-, eremophilane- and bicyclofarnesane-type sesquiterpenes according to the 

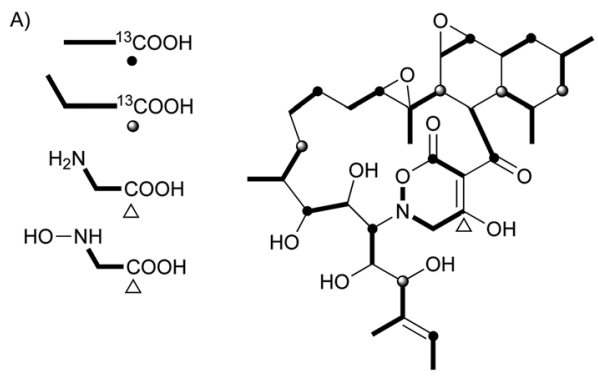

B)

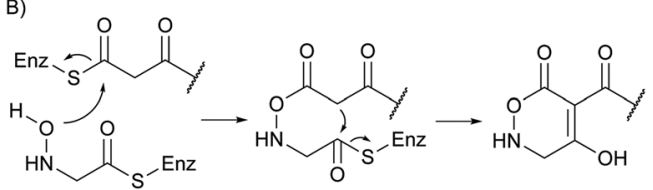

Fig. 6 Biosynthetic investigation for 188. (A) Incorporation of ${ }^{13} \mathrm{C}$ labeled precursors into 188. (B) Proposed biosynthetic pathway for tetrahydrooxazine ring.

classification in earlier reviews. ${ }^{4-6}$ Cadinane sesquiterpenes have demonstrated highly selective and notable nematicidal activities, but have remained largely inactive in antimicrobial and cytotoxic assays. ${ }^{185-189}$ Eremophilane sesquiterpenes, typically isolated from fungi of the genera Xylaria and Penicillium exhibit diverse biological properties, such as cytotoxic, ${ }^{190,191}$ antimicrobial, ${ }^{192}$ and inhibition of HIV integrase. ${ }^{193}$ More importantly, most of the bicyclofarnesane-type sesquiterpenes are composed of an isoprenoid-derived decalin ring system linked to a polyketide ring unit with some substituted functionalized groups such as an amino acid. The typical diverse structures of this family are the compounds 196, ${ }^{194} 197,{ }^{195} 198,{ }^{195} 199,{ }^{196} 200,{ }^{197} 201,{ }^{198}$ 202, ${ }^{198} 203,{ }^{199}$ and $204 .{ }^{200}$ The proposed biosynthesis of compound 196 is shown in Scheme 24 (see Supporting Information of ref. 194). Similarly, a coupling between a polyketide-derived pyranone or pyrone and a diterpene (decalin part) contribute to the structural diversity of the diterpenes $205^{201}$ and 206. ${ }^{202,203}$

\section{Conclusions}

A number of bioactive microbial secondary metabolites with the decalin scaffold are increasingly being discovered. Herein, we present a comprehensive review on nearly 200 polyketide decalin secondary metabolites and 11 representative sesquiterpenoids and diterpenoids with the decalin system. The structural diversity of decalin-derived microbial natural<smiles>CC1=CC[C@@H]2[C@@H](CCCC2(C)C)C1CC12OC1C(=O)C(CO)=C[C@H]2O</smiles><smiles>Cc1cc(O)c2c3c1OC1CC[C@H]4C(C)C(=O)CCC4(C)C3CC1=C2C=O</smiles>

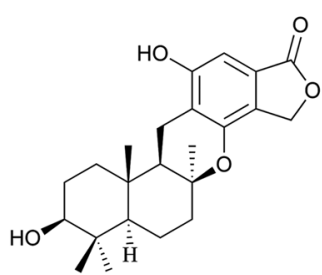

198

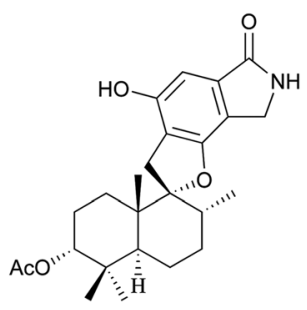

202<smiles>Cc1c2c(cc(O)c1O[C@@]13CC[C@@H](O)[C@@H](C)[C@@H]1CCC(C)C3C)C(=O)NC2</smiles>

199

200

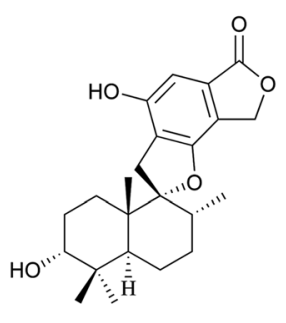

201<smiles>C=C1CC[C@@H]2[C@@H](CCC=C(C)C)[C@@H](OC(C)=O)CC[C@]2(C)[C@@H]1Cc1c(O)c(C)c(C)oc1=O</smiles><smiles>COc1oc(C)c(C)c(=O)c1CC1C(=O)CC[C@H]2C3(C)CC(O)[C@@H](C(C)(C)O)O[C@H]3CC[C@]12C</smiles>

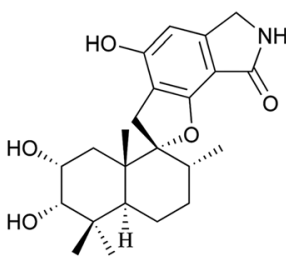

204 

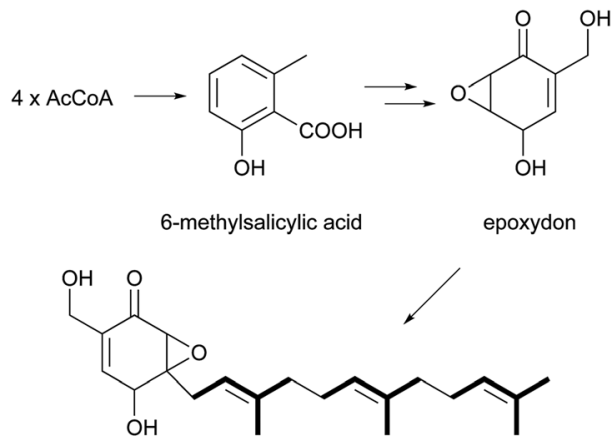

yanuthone-like intermediate

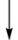

196

Scheme 24 The proposed biosynthesis for 196 .

products is a consequence of the large manifold of fungal or bacterial species, and also a result of the biosynthetic capability of these fascinating producers to assemble decalin compounds in single or mixed biosynthetic pathways. Furthermore, they display diverse and remarkable biological activities.

More importantly, nearly all the polyketide decalin-derived compounds we have discussed in this manuscript have a double bond between C3 and C4 (sometimes oxygenated), suggesting an enzymatic or non-enzymatic IMDA cycloaddition to form the decalin scaffold. Moreover, all the decalin-containing secondary metabolites presented here seem to be assembled by a linear polyketide or isoprenoid unit, which then cyclize to the decalin scaffold followed by incorporation of functionalized substituted groups. This suggests that the biosynthetic pathways of many of these compounds are extremely related, as exemplified in this review. Specifically, the decalin cyclization type endo-trans-fused one (C or D) is the most common, even though two other fused classes are dominant in some classifications, such as the pyrone derivatives (exo-cis-fused, A) and macrolides (exo-cis-fused, B). This phenomenon may be the result of a steric or enzymatic effect. Lastly, compounds with the decalin system conjoining different functionalized moieties such as lactones in monacolins and tetramic acids often have different biological activities. Therefore, these intriguing similarities or differences prove helpful in elucidating their biosynthesis and might provide a scientific handle for aiding biomimetic total synthesis. Finally, the decalin scaffold is more likely to serve as the rigid or basic template for construction of the whole structure.

\section{Acknowledgements}

G.L. gratefully acknowledges the China Scholarship Council (CSC) for a doctoral fellowship. S.K. was a Visiting Researcher at the Department of Plant Sciences, University of Oxford, South Parks Road, Oxford OX1 3RB, UK, during preparation of the manuscript (Apr 2013 to Mar 2014). S.K. gratefully acknowledges Dr Gail M. Preston for hosting and TU Dortmund for supporting his stay at the University of Oxford. The authors are grateful to Prof. Michael Müller of the University of Freiburg, Germany for valuable comments and suggestions.

\section{References}

1 E. M. Stocking and R. M. Williams, Angew. Chem., Int. Ed., 2003, 42, 3078-3115.

2 K. Uchida, T. Ogawa, Y. Yasuda, H. Mimura, T. Fujimoto, T. Fukuyama, T. Wakimoto, T. Asakawa, Y. Hamashima and T. Kan, Angew. Chem., Int. Ed., 2012, 51, 12850-12853.

3 V. Singh, S. R. Iyer and S. Pal, Tetrahedron, 2005, 61, 91979231.

4 B. M. Fraga, Nat. Prod. Rep., 2013, 30, 1226-1264.

5 J. R. Hanson, Nat. Prod. Rep., 2009, 26, 1156-1171.

6 J. R. Hanson, Nat. Prod. Rep., 2013, 30, 1346-1356.

7 W. L. Kelly, Org. Biomol. Chem., 2008, 6, 4483-4493.

8 H. J. Kim, M. W. Ruszczycky, S.-h. Choi, Y.-n. Liu and H.-w. Liu, Nature, 2011, 473, 109-112.

9 K. Auclair, A. Sutherland, J. Kennedy, D. J. Witter, J. P. Van den Heever, C. R. Hutchinson and J. C. Vederas, J. Am. Chem. Soc., 2000, 122, 11519-11520.

10 K. Kasahara, T. Miyamoto, T. Fujimoto, H. Oguri, T. Tokiwano, H. Oikawa, Y. Ebizuka and I. Fujii, ChemBioChem, 2010, 11, 1245-1252.

11 T. R. Hoye and V. Dvornikovs, J. Am. Chem. Soc., 2006, 128, 2550-2551.

12 M. A. Varner and R. B. Grossman, Tetrahedron, 1999, 55, 13867-13886.

13 T. Tokoroyama, Synthesis, 2000, 611-633.

14 H. Akita, Heterocycles, 2013, 87, 1625-1658.

15 E. S. Istvan and J. Deisenhofer, Science, 2001, 292, 1160-1164.

16 W. Xu, Y.-H. Chooi, J. W. Choi, S. Li, J. C. Vederas, N. A. Da

Silva and Y. Tang, Angew. Chem., Int. Ed., 2013, 52, 6472-6475. 17 A. Endo, J. Antibiot., 1979, 32, 852-854.

18 A. Endo, J. Antibiot., 1980, 33, 334-336.

19 A. W. Alberts, J. Chen, G. Kuron, V. Hunt, J. Huff, C. Hoffman, J. Rothrock, M. Lopez, H. Joshua, E. Harris, A. Patchett, R. Monaghan, S. Currie, E. Stapley, G. AlbersSchonberg, O. Hensens, J. Hirshfield, K. Hoogsteen, J. Liesch and J. Springer, Proc. Natl. Acad. Sci. U. S. A., 1980, 77, 3957-3961.

20 J. Kennedy, K. Auclair, S. G. Kendrew, C. Park, J. C. Vederas and C. R. Hutchinson, Science, 1999, 284, 1368-1372.

21 X. Xie, M. J. Meehan, W. Xu, P. C. Dorrestein and Y. Tang, J. Am. Chem. Soc., 2009, 131, 8388-8389.

22 J. Barriuso, D. T. Nguyen, J. W.-H. Li, J. N. Roberts, G. MacNevin, J. L. Chaytor, S. L. Marcus, J. C. Vederas and D.-K. Ro, J. Am. Chem. Soc., 2011, 133, 8078-8081.

23 B. D. Ames, C. Nguyen, J. Bruegger, P. Smith, W. Xu, S. Ma, E. Wong, S. Wong, X. Xie, J. W.-H. Li, J. C. Vederas, Y. Tang and S.-C. Tsai, Proc. Natl. Acad. Sci. U. S. A., 2012, 109, 11144-11149.

24 G. Albers-Schönberg, H. Joshua, M. B. Lopez, O. D. Hensens, J. P. Springer, J. Chen, S. Ostrove, 
C. H. Hoffman, A. W. Alberts and A. A. Patchett, J. Antibiot., 1981, 34, 507-512.

25 A. Endo, K. Hasumi and S. Negishi, J. Antibiot., 1985, 38, 420-422.

26 A. Endo, K. Hasumi, T. Nakamura, M. Kunishima and M. Masuda, J. Antibiot., 1985, 38, 321-327.

27 A. Endo, D. Komagata and H. Shimada, J. Antibiot., 1986, 39, 1670-1673.

28 L. R. Treiber, R. A. Reamer, C. S. Rooney and H. G. Ramjit, J. Antibiot., 1989, 42, 30-36.

29 A. G. Brown, T. C. Smale, T. J. King, R. Hasenkamp and R. H. Thompson, J. Chem. Soc., Perkin Trans. 1, 1976, 1165-1170.

30 A. Endo, M. Kuroda and Y. Tsujita, J. Antibiot., 1976, 29, 1346-1348.

31 Y. K. Tony Lam, V. P. Gullo, R. T. Goegelman, D. Jorn, L. Huang, C. DeRiso, R. L. Monaghan and I. Putter, J. Antibiot., 1981, 34, 614-616.

32 S. Murakawa, K. Sakai and A. Endo, J. Antibiot., 1994, 47, 108-109.

33 S. Okamoto, T. Hosoe, T. Itabashi, K. Nozawa, K. Okada, G. M. de C. Takaki, M. Chikamori, T. Yaguchi, K. Fukushima, M. Miyaji and K. Kawai, J. Nat. Prod., 2004, 67, 1580-1583.

34 M.-T. Liu, J.-J. Li, X.-Y. Shang, S. Li, L.-L. Li, N. Luan and Z.-L. Jin, Magn. Reson. Chem., 2011, 49, 129-131.

35 M.-T. Liu, N. Luan, J.-J. Li, X. Huang, Y.-F. Wang, A.-L. Wang and X.-Y. Shang, Magn. Reson. Chem., 2012, 50, 709712.

36 L. Zhu, L.-F. Yau, J.-G. Lu, G.-Y. Zhu, J.-R. Wang, Q.-B. Han, W.-L. Hsiao and Z.-H. Jiang, J. Agric. Food Chem., 2012, 60, 934-939.

37 L. Zhu, J.-G. Lu, T. Li, G.-Y. Zhu, Q.-B. Han, W.-L. Hsiao, L. Liu and Z.-H. Jiang, J. Nat. Prod., 2012, 75, 567-571.

38 Y.-T. Zhang, Y. Wang, X.-T. Zhang, D.-L. Wu, X.-Q. Zhang and W.-C. Ye, J. Asian Nat. Prod. Res., 2009, 11, 792-795.

39 I. Barash, G. Pupkin, D. Netzer and Y. Kashman, Plant Physiol., 1982, 69, 23-27.

40 I. Barash, S. Manulis, Y. Kashman, J. P. Springer, M. H. M. Chen, J. Clardy and G. A. Strobel, Science, 1983, 220, 1065-1066.

41 S. Manulis, Y. Kashman, D. Netzert and I. Barash, Phytochemistry, 1984, 23, 2193-2198.

42 I. Barash and S. Manulis, in Iron, Siderophores, and Plant Diseases, Springer 1986, 117, pp. 273-281.

43 A. Ichihara, H. Oikawa, K. Hayashi, S. Sakamura, A. Furusaki and T. Matsumoto, J. Am. Chem. Soc., 1983, 105, 2907-2908.

44 A. Ichihara, H. Oikawa, M. Hashimoto, S. Sakamura, T. Haraguchi and H. Nagano, Agric. Biol. Chem., 1983, 47, 2965-2967.

45 H. Oikawa, A. Ichihara and S. Sakamura, J. Chem. Soc., Chem. Commun., 1984, 814-815.

46 H. Oikawa, A. Ichihara and S. Sakamura, J. Chem. Soc., Chem. Commun., 1988, 600-602.

47 M. Kobayashi, H. Uehara, K. Matsunami, S. Aoki and I. Kitagawa, Tetrahedron Lett., 1993, 34, 7925-7928.
48 W. S. Horn, R. E. Schwartz, M. S. J. Simmonds and W. M. Blaney, Tetrahedron Lett., 1994, 35, 6037-6040.

49 R. Sawa, Y. Takahashi, S. Itoh, K. Shimanaka, N. Kinoshita, Y. Homma, M. Hamada, T. Sawa, H. Naganawa and T. Takeuchi, J. Antibiot., 1994, 47, 1266-1272.

50 O. D. Hensens, G. L. Helms, E. T. T. Jones and G. H. Harris, J. Org. Chem., 1995, 60, 1772-1776.

51 L. Rahbæk, S. Sperry, J. E. Piper and P. Crews, J. Nat. Prod., 1998, 61, 1571-1573.

52 G. Brauers, R. A. Edrada, R. Ebel, P. Proksch, V. Wray, A. Berg, U. Gräfe, C. Schächtele, F. Totzke, G. Finkenzeller, D. Marme, J. Kraus, M. Münchbach, M. Michel, G. Bringmann and K. Schaumann, J. Nat. Prod., 2000, 63, 739-745.

53 Y. Fujii, M. Asahara, M. Ichinoe and H. Nakajima, Phytochemistry, 2002, 60, 703-708.

54 S. Tsukamoto, S. Miura, Y. Yamashita and T. Ohta, Bioorg. Med. Chem. Lett., 2004, 14, 417-420.

55 Y. Ohtsu, S. Yoshimura, T. Kinoshita, S. Takase and H. Nakajima, J. Antibiot., 2005, 58, 479-482.

56 S. Nakadate, K. Nozawa, H. Horie, Y. Fujii, M. Nagai, T. Hosoe, K. Kawai, T. Yaguchi and K. Fukushima, J. Nat. Prod., 2007, 70, 1510-1512.

57 T. Yamada, Y. Mizutani, Y. Umebayashi, N. Inno, M. Kawashima, T. Kikuchi and R. Tanaka, Tetrahedron Lett., 2014, 55, 662-664.

58 M. Kuramoto, K. Yamada, M. Shikano, K. Yazawa, H. Arimoto, T. Okamura and D. Uemura, Chem. Lett., 1997, 885-886.

59 J. Malmstrøm, C. Christophersen and J. C. Frisvad, Phytochemistry, 2000, 54, 301-309.

60 M. El-Neketi, W. Ebrahim, W. Lin, S. Gedara, F. Badria, H.-E. A. Saad, D. Lai and P. Proksch, J. Nat. Prod., 2013, 76, 1099-1104.

61 L. P. Sandjo, E. Thines, T. Opatz and A. Schüffler, Beilstein J. Org. Chem., 2014, 10, 251-258.

62 N. Tabata, H. Tomoda, R. Masuma, K. Haneda, Y. Iwai and S. Ōmura, J. Antibiot., 1993, 46, 1849-1853.

63 R. Masuma, N. Tabata, H. Tomoda, K. Haneda, Y. Iwai and S. Ōmura, J. Antibiot., 1994, 47, 46-53.

64 J. G. Ondeyka, R. A. Giacobbe, G. F. Bills, C. Cuadrillero, D. Schmatz, M. A. Goetz, D. L. Zink and S. B. Singh, Bioorg. Med. Chem. Lett., 1998, 8, 3439-3442.

65 M. Namikoshi, H. Kobayashi, T. Yoshimoto and T. Hosoya, J. Antibiot., 1997, 50, 890-892.

66 H. Kobayashi, S. Meguro, T. Yoshimoto and M. Namikoshi, Tetrahedron, 2003, 59, 455-459.

67 C. A. Parish, M. de la Cruz, S. K. Smith, D. Zink, J. Baxter, S. Tucker-Samaras, J. Collado, G. Platas, G. Bills, M. T. Díez, F. Vicente, F. Peláez and K. Wilson, J. Nat. Prod., 2009, 72, 59-62.

68 H. Kobayashi, R. Sunaga, K. Furihata, N. Morisaki and S. Iwasaki, J. Antibiot., 1995, 48, 42-52.

69 H. P. Nguyen, D. Zhang, U. Lee, J. S. Kang, H. D. Choi and B. W. Son, J. Nat. Prod., 2007, 70, 1188-1190.

70 H. Kumagai, T. Someno, K. Dobashi, K. Isshiki, M. Ishizuka and D. Ikeda, J. Antibiot., 2004, 57, 97-103. 
71 M. I. Mitova, G. Lang, J. W. Blunt, N. J. Cummings, A. L. J. Cole, W. T. Robinson and M. H. G. Munro, J. Org. Chem., 2006, 71, 492-497.

72 D. B. Stierle, A. A. Stierle and B. K. Ganser, J. Nat. Prod., 1999, 62, 1147-1150.

73 S. Sakamoto, F. Kojima, M. Igarashi, R. Sawa, M. Umekita, Y. Kubota, K. Nakae, S. Yamaguchi, H. Adachi, Y. Nishimura and Y. Akamatsu, J. Antibiot., 2010, 63, 703-708.

74 S. Sakamoto, F. Kojima, I. Momose, M. Kawada, H. Adachi and Y. Nishimura, Biochem. Biophys. Res. Commun., 2012, 422, 751-757.

75 H. Oikawa, T. Yokota, A. Ichihara and S. Sakamura, J. Chem. Soc., Chem. Commun., 1989, 1284-1285.

76 H. Oikawa, Y. Suzuki, A. Naya, K. Katayama and A. Ichihara, J. Am. Chem. Soc., 1994, 116, 3605-3606.

77 A. Ichihara, H. Tazaki and S. Sakamura, Tetrahedron Lett., 1983, 24, 5373-5376.

78 Y. Mizushina, S. Kamisuki, N. Kasai, N. Shimazaki, M. Takemura, H. Asahara, S. Linn, S. Yoshida, A. Matsukage, O. Koiwai, F. Sugawara, H. Yoshida and K. Sakaguchi, J. Biol. Chem., 2002, 277, 630-638.

79 H. Oikawa, T. Yokota, C. Sakano, Y. Suzuki, A. Naya and A. Ichihara, Biosci., Biotechnol., Biochem., 1998, 62, 20162022.

80 H. Hagiwara, K. Kobayashi, S. Miya, T. Hoshi, T. Suzuki, M. Ando, T. Okamoto, M. Kobayashi, I. Yamamoto, S. Ohtsubo, M. Kato and H. Uda, J. Org. Chem., 2002, 67, 5969-5976.

81 B. Lygo, M. Bhatia, J. W. B. Cooke and D. J. Hirst, Tetrahedron Lett., 2003, 44, 2529-2532.

82 R. M. Wilson, W. S. Jen and D. W. C. MacMillan, J. Am. Chem. Soc., 2005, 127, 11616-11617.

83 K. M. Jenkins, S. G. Toske, P. R. Jensen and W. Fenical, Phytochemistry, 1998, 49, 2299-2304.

84 L. E. Schmidt, J. B. Gloer and D. T. Wicklow, J. Nat. Prod., 2007, 70, 1317-1320.

85 K. Trisuwan, V. Rukachaisirikul, Y. Sukpondma, S. Preedanon, S. Phongpaichit and J. Sakayaroj, Phytochemistry, 2009, 70, 554-557.

86 H. A. Whaley, C. G. Chidester, S. A. Mizsak and R. J. Wnuk, Tetrahedron Lett., 1980, 21, 3659-3662.

87 W. D. Celmer, G. N. Chmurny, C. E. Moppett, R. S. Ware, P. C. Watts and E. B. Whipple, J. Am. Chem. Soc., 1980, 102, 4203-4209.

88 W. C. Snyder and K. L. Rinehart, Jr, J. Am. Chem. Soc., 1984, 106, 787-789.

89 R. R. Rasmussen, M. H. Scherr, D. N. Whittern, A. M. Buko and J. B. McAlpine, J. Antibiot., 1987, 40, 1383-1393.

90 H. Gouda, T. Sunazuka, H. Ui, M. Handa, Y. Sakoh, Y. Iwai, S. Hirono and S. Ōmura, Proc. Natl. Acad. Sci. U. S. A., 2005, 102, 18286-18291.

91 J. B. McAlpine, L. A. Mitscher, M. Jackson, R. R. Rasmussen, D. V. Velde and E. Veliz, Tetrahedron, 1996, 52, 1032710334.

92 K. Gerth, H. Steinmetz, G. Höfle and R. Jansen, Angew. Chem., Int. Ed., 2008, 47, 600-602.
93 N. Rahn and M. Kalesse, Angew. Chem., Int. Ed., 2008, 47, 597-599.

94 K. H. Jang, S.-J. Nam, J. B. Locke, C. A. Kauffman, D. S. Beatty, L. A. Paul and W. Fenical, Angew. Chem., Int. Ed., 2013, 52, 7822-7824.

95 B. J. Royles, Chem. Rev., 1995, 95, 1981-2001.

96 R. Schobert and A. Schlenk, Bioorg. Med. Chem., 2008, 16, 4203-4221.

97 B. Nay, N. Riache and L. Evanno, Nat. Prod. Rep., 2009, 26, 1044-1062.

98 H. R. Burmeister, G. A. Bennett, R. F. Vesonder and C. W. Hesseltine, Antimicrob. Agents Chemother., 1974, 5, 634-639.

99 R. F. Vesonder, L. W. Tjarks, W. K. Rohwedder, H. R. Burmeister and J. A. Laugal, J. Antibiot., 1979, 32, 759-761.

100 E. C. Marfori, T. Bamba, S. Kajiyama, E. Fukusaki and A. Kobayashi, Tetrahedron, 2002, 58, 6655-6658.

101 D. Boettger and C. Hertweck, ChemBioChem, 2013, 14, 2842.

102 J. W. Sims and E. W. Schmidt, J. Am. Chem. Soc., 2008, 130, 11149-11155.

103 E. Turos, J. E. Audia and S. J. Danishefsky, J. Am. Chem. Soc., 1989, 111, 8231-8236.

104 K. Yuki, M. Shindo and K. Shishido, Tetrahedron Lett., 2001, 42, 2517-2519.

105 L. T. Burke, D. J. Dixon, S. V. Ley and F. Rodríguez, Org. Biomol. Chem., 2005, 3, 274-280.

106 J. Yin, L. Kong, C. Wang, Y. Shi, S. Cai and S. Gao, Chem.Eur. J., 2013, 19, 13040-13046.

107 S. B. Singh, D. L. Zink, M. A. Goetz, A. W. Dombrowski, J. D. Polishook and D. J. Hazuda, Tetrahedron Lett., 1998, 39, 2243-2246.

108 J. Y. Li, G. Strobel, J. Harper, E. Lobkovsky and J. Clardy, Org. Lett., 2000, 2, 767-770.

109 V. Hellwig, T. Grothe, A. Mayer-Bartschmid, R. Endermann, F.-U. Geschke, T. Henkel and M. Stadler, J. Antibiot., 2002, 55, 881-892.

110 M. P. Segeth, A. Bonnefoy, M. Brönstrup, M. Knauf, D. Schummer, L. Toti, L. Vértesy, M.-C. Wetzel-Raynal, J. Wink and G. Seibert, J. Antibiot., 2003, 56, 114-122.

111 E. C. Marfori, S. Kajiyama, E. Fukusaki and A. Kobayashi, Z. Naturforsch., 2002, 57c, 465-470.

112 C. Boros, A. Dix, B. Katz, Y. Vasina and C. Pearce, J. Antibiot., 2003, 56, 862-865.

113 S. P. Putri, H. Kinoshita, F. Ihara, Y. Igarashi and T. Nihira, J. Antibiot., 2010, 63, 195-198.

114 J. Whitt, S. M. Shipley, D. J. Newman and K. M. Zuck, J. Nat. Prod., 2014, 77, 173-177.

115 T. Amagata, J. Xiao, Y.-P. Chen, N. Holsopple, A. G. Oliver, T. Gokey, A. B. Guliaev and K. Minoura, J. Nat. Prod., 2012, 75, 2193-2199.

116 K. Herath, H. Jayasuriya, D. L. Zink, J. Sigmund, F. Vicente, M. de la Cruz, A. Basilio, G. F. Bills, J. D. Polishook, R. Donald, J. Phillips, M. Goetz and S. B. Singh, J. Nat. Prod., 2012, 75, 420-424. 
117 Y. Sugie, K. A. Dekker, T. Inagaki, Y.-J. Kim, T. Sakakibara, S. Sakemi, A. Sugiura, L. Brennan, J. Duignan, J. A. Sutcliffe and Y. Kojima, J. Antibiot., 2002, 55, 19-24.

118 Y. Sugie, S. Inagaki, Y. Kato, H. Nishida, C.-H. Pang, T. Saito, S. Sakemi, F. Dib-Hajj, J. P. Mueller, J. Sutcliffe and Y. Kojima, J. Antibiot., 2002, 55, 25-29.

119 C. Osterhage, R. Kaminsky, G. M. König and A. D. Wright, J. Org. Chem., 2000, 65, 6412-6417.

120 S. Toda, S. Yamamoto, O. Tenmyo, T. Tsuno, T. Hasegawa, M. Rosser, M. Oka, Y. Sawada, M. Konishi and T. Oki, J. Antibiot., 1993, 46, 875-883.

121 M. Ueno, T. Someno, R. Sawa, H. Iinuma, H. Naganawa, M. Ishizuka and T. Takeuchi, J. Antibiot., 1993, 46, 979-984. 122 S.-W. Yang, R. Mierzwa, J. Terracciano, M. Patel, V. Gullo, N. Wagner, B. Baroudy, M. Puar, T.-M. Chan, A. T. McPhail and M. Chu, J. Nat. Prod., 2006, 69, 10251028.

123 Y.-L. Yang, C.-P. Lu, M.-Y. Chen, K.-Y. Chen, Y.-C. Wu and S.-H. Wu, Chem.-Eur. J., 2007, 13, 6985-6991.

124 S. B. Singh, M. A. Goetz, E. T. Jones, G. F. Bills, R. A. Giacobbe, L. Herranz, S. Stevens-Miles and D. L. Williams, Jr, J. Org. Chem., 1995, 60, 7040-7042.

125 R. R. West, J. Van Ness, A.-M. Varming, B. Rassing, S. Biggs, S. Gasper, P. A. Mckernan and J. Piggott, J. Antibiot., 1996, 49, 967-973.

126 R. Kontnik and J. Clardy, Org. Lett., 2008, 10, 4149-4151.

127 S. B. Singh, D. L. Zink, B. Heimbach, O. Genilloud, A. Teran, K. C. Silverman, R. B. Lingham, P. Felock and D. J. Hazuda, Org. Lett., 2002, 4, 1123-1126.

128 Y. Hayakawa, N. Kanamaru, A. Shimazu and H. Seto, J. Antibiot., 1991, 44, 282-287.

129 Y. Hayakawa, N. Kanamaru, N. Morisaki, H. Seto and K. Furihata, Tetrahedron Lett., 1991, 32, 213-216.

130 T. Furumai, K. Eto, T. Sasaki, H. Higuchi, H. Onaka, N. Saito, T. Fujita, H. Naoki and Y. Igarashi, J. Antibiot., 2002, 55, 873-880.

131 J. W. Phillips, M. A. Goetz, S. K. Smith, D. L. Zink, J. Polishook, R. Onishi, S. Salowe, J. Wiltsie, J. Allocco, J. Sigmund, K. Dorso, S. Lee, S. Skwish, M. de la Cruz, J. Martín, F. Vicente, O. Genilloud, J. Lu, R. E. Painter, K. Young, K. Overbye, R. G. K. Donald and S. B. Singh, Chem. Biol., 2011, 18, 955-965.

132 S. B. Singh, M. A. Goetz, S. K. Smith, D. L. Zink, J. Polishook, R. Onishi, S. Salowe, J. Wiltsie, J. Allocco, J. Sigmund, K. Dorso, M. de la Cruz, J. Martín, F. Vicente, O. Genilloud, R. G. K. Donald and J. W. Phillips, Bioorg. Med. Chem. Lett., 2012, 22, 7127-7130.

133 R. Sawa, Y. Takahashi, H. Hashizume, K. Sasaki, Y. Ishizaki, M. Umekita, M. Hatano, H. Abe, T. Watanabe, N. Kinoshita, Y. Homma, C. Hayashi, K. Inoue, S. Ohba, T. Masuda, M. Arakawa, Y. Kobayashi, M. Hamada, M. Igarashi, H. Adachi, Y. Nishimura and Y. Akamatsu, Chem.-Eur. J., 2012, 18, 15772-15781.

134 H. J. Jessen and K. Gademann, Nat. Prod. Rep., 2010, 27, 1168-1185.

135 A. A. Alfatafta, J. B. Gloer, J. A. Scott and D. Malloch, J. Nat. Prod., 1994, 57, 1696-1702.
136 H. Fujimoto, M. Ikeda, K. Yamamoto and M. Yamazaki, J. Nat. Prod., 1993, 56, 1268-1275.

137 S. Bergmann, J. Schümann, K. Scherlach, C. Lange, A. A. Brakhage and C. Hertweck, Nat. Chem. Biol., 2007, 3, 213-217.

138 M. Shibazaki, M. Taniguchi, T. Yokoi, K. Nagai, M. Watanabe, K. Suzuki and T. Yamamoto, J. Antibiot., 2004, 57, 379-382.

139 J. C. Lee, S. J. Coval and J. Clardy, J. Antibiot., 1996, 49, 693696.

140 A. Haga, H. Tamoto, M. Ishino, E. Kimura, T. Sugita, K. Kinoshita, K. Takahashi, M. Shiro and K. Koyama, J. Nat. Prod., 2013, 76, 750-754.

141 S. Hayakawa, H. Minato and K. Katagiri, J. Antibiot., 1971, 24, 653-654.

142 E. B. Gutierrez-Cirlos, T. Merbitz-Zahradnik and B. L. Trumpower, J. Biol. Chem., 2004, 279, 8708-8714.

143 M. Tanabe and S. Urano, Tetrahedron, 1983, 39, 3569-3574. 144 S. B. Singh, X. Li and T. Chen, Tetrahedron Lett., 2011, 52, 6190-6191.

145 W. Keller-Schierlein, R. Muntwyler, W. Pache and H. Zähner, Helv. Chim. Acta, 1969, 52, 127-142.

146 F. Tomita, T. Tamaoki, K. Shirahata, M. Kasai, M. Morimoto, S. Ohkubo, K. Mineura and S. Ishii, J. Antibiot., 1980, 33, 668-670.

147 K. Kobinata, M. Uramoto, T. Mizuno and K. Isono, J. Antibiot., 1980, 33, 244-246.

148 J. A. Waitz, A. Horan, M. Kalyanpur, B. K. Lee, D. Loebenberg, J. A. Marquez, G. Miller and M. G. Patel, J. Antibiot., 1981, 34, 1101-1106.

149 A. K. Mallams, M. S. Puar and R. R. Rossman, J. Am. Chem. Soc., 1981, 103, 3938-3940.

150 A. K. Mallams, M. S. Puar, R. R. Rossman, A. T. McPhail and R. D. Macfarlane, J. Am. Chem. Soc., 1981, 103, 3940-3943.

151 H. Zhang, J. A. White-Phillip, C. E. Melançon, H.-j. Kwon, W.-l. Yu and H.-w. Liu, J. Am. Chem. Soc., 2007, 129, 14670-14683.

152 A. Kawashima, Y. Nakamura, Y. Ohta, T. Akama, M. Yamagishi and K. Hanada, J. Antibiot., 1992, 45, 207212.

153 P. W. Schindler and M. C. Scrutton, Eur. J. Biochem., 1975, 55, 543-553.

154 I. Tinhofer, G. Anether, M. Senfter, K. Pfaller, D. Bernhard, M. Hara and R. Greil, FASEB J., 2002, 16, 1295-1297.

155 T. Nakashima, M. Miura and M. Hara, Cancer Res., 2000, 60, 1229-1235.

156 G. Anether, I. Tinhofer, M. Senfter and R. Greil, Blood, 2003, 101, 4561-4568.

157 H. Nakajima, K. Sakaguchi, I. Fujiwara, M. Mizuta, M. Tsuruga, J. Magae and N. Mizuta, Biochem. Biophys. Res. Commun., 2007, 356, 260-265.

158 X.-Y. Jia, Z.-H. Tian, L. Shao, X.-D. Qu, Q.-F. Zhao, J. Tang, G.-L. Tang and W. Liu, Chem. Biol., 2006, 13, 575-585.

159 J. Fang, Y. Zhang, L. Huang, X. Jia, Q. Zhang, X. Zhang, G. Tang and W. Liu, J. Bacteriol., 2008, 190, 6014-6025.

160 J. J. Lee, J. P. Lee, P. J. Keller, C. E. Cottrell, C.-J. Chang, H. Zähner and H. G. Floss, J. Antibiot., 1986, 39, 1123-1134. 
161 Y. Sun, H. Hong, F. Gillies, J. B. Spencer and P. F. Leadlay, ChemBioChem, 2008, 9, 150-156.

162 W. R. Roush and R. J. Sciotti, J. Am. Chem. Soc., 1994, 116, 6457-6458.

163 W. R. Roush and R. J. Sciotti, J. Am. Chem. Soc., 1998, 120, 7411-7419.

164 K. Takeda, Y. Igarashi, K. Okazaki, E. Yoshii and K. Yamaguchi, J. Org. Chem., 1990, 55, 3431-3434.

165 K. Takeda, H. Kato, H. Sasahara and E. Yoshii,J. Chem. Soc., Chem. Commun., 1986, 1197-1198.

166 K. Takeda, E. Kawanishi, H. Nakamura and E. Yoshii, Tetrahedron Lett., 1991, 32, 4925-4928.

167 R. K. Boeckman, Jr., P. Shao, S. T. Wrobleski, D. J. Boehmler, G. R. Heintzelman and A. J. Barbosa, J. Am. Chem. Soc., 2006, 128, 10572-10588.

168 W. R. Roush, C. Limberakis, R. K. Kunz and D. A. Barda, Org. Lett., 2002, 4, 1543-1546.

169 D. Niu and T. R. Hoye, Org. Lett., 2012, 14, 828-831.

170 R. Nakai, H. Ogawa, A. Asai, K. Ando, T. Agatsuma, S. Matsumiya, S. Akinaga, Y. Yamashita and T. Mizukami, J. Antibiot., 2000, 53, 294-296.

171 T. Agatsuma, T. Akama, S. Nara, S. Matsumiya, R. Nakai, H. Ogawa, S. Otaki, S. Ikeda, Y. Saitoh and Y. Kanda, Org. Lett., 2002, 4, 4387-4390.

172 T. H. Lambert and S. J. Danishefsky, J. Am. Chem. Soc., 2006, 128, 426-427.

173 T. R. Hoye, V. Dvornikovs and E. Sizova, Org. Lett., 2006, 8, 5191-5194.

174 R. M. de Figueiredo, M. Voith, R. Fröhlich and M. Christmann, Synlett., 2007, 3, 391-394.

175 R. M. de Figueiredo, R. Fröhlich and M. Christmann, Angew. Chem., Int. Ed., 2007, 46, 2883-2886.

176 Y. Sugie, H. Hirai, H. Kachi-Tonai, Y.-J. Kim, Y. Kojima, Y. Shiomi, A. Sugiura, Y. Suzuki, N. Yoshikawa, L. Brennan, J. Duignan, L. H. Huang, J. Sutcliffe and N. Kojima, J. Antibiot., 2001, 54, 917-925.

177 T. Nogawa, M. Kawatani, M. Uramoto, A. Okano, H. Aono, Y. Futamura, H. Koshino, S. Takahashi and H. Osada, J. Antibiot., 2013, 66, 621-623.

178 Y. Futamura, M. Kawatani, M. Muroi, H. Aono, T. Nogawa and H. Osada, ChemBioChem, 2013, 14, 2456-2463.

179 Y. Igarashi, Y. Kim, Y. In, T. Ishida, Y. Kan, T. Fujita, T. Iwashita, H. Tabata, H. Onaka and T. Furumai, Org. Lett., 2010, 12, 3402-3405.

180 Y. Kim, Y. In, T. Ishida, H. Onaka and Y. Igarashi, Org. Lett., 2013, 15, 3514-3517.

181 C. Klemke, S. Kehraus, A. D. Wright and G. M. König, J. Nat. Prod., 2004, 67, 1058-1063.

182 D. E. Williams, D. S. Dalisay, F. Li, J. Amphlett, W. Maneerat, M. A. G. Chavez, Y. A. Wang, T. Matainaho, W. Yu, P. J. Brown, C. H. Arrowsmith, M. Vedadi and R. J. Andersen, Org. Lett., 2013, 15, 414-417.
183 J. C. Arens, F. Berrué, J. K. Pearson and R. G. Kerr, Org. Lett., 2013, 15, 3864-3867.

184 T. Tsuchida, H. Iinuma, C. Nishida, N. Kinoshita, T. Sawa, M. Hamada and T. Takeuchi, J. Antibiot., 1995, 48, 1104-1109.

185 F. Hiramatsu, T. Murayama, T. Koseki, K. Okada and Y. Shiono, Helv. Chim. Acta, 2008, 91, 1595-1603.

186 F. Hiramatsu, T. Murayama, T. Koseki and Y. Shiono, Phytochemistry, 2007, 68, 1267-1271.

187 M. Clericuzio, R. Negri, M. Cossi, G. Gilardoni, D. Gozzini and G. Vidari, Phytochemistry, 2013, 93, 192-198.

188 Y. Shiono, F. Hiramatsu, T. Murayama, T. Koseki, T. Funakoshi, K. Ueda and H. Yasuda, Z. Naturforsch, 2007, 62b, 1585-1589.

189 G.-H. Li, M. Duan, Z.-F. Yu, L. Li, J.-Y. Dong, X.-B. Wang, J.-W. Guo, R. Huang, M. Wang and K.-Q. Zhang, Phytochemistry, 2008, 69, 1439-1445.

190 G. Wu, A. Lin, Q. Gu, T. Zhu and D. Li, Mar. Drugs, 2013, 11, 1399-1408.

191 H. Oh, P. R. Jensen, B. T. Murphy, C. Fiorilla, J. F. Sullivan, T. Ramsey and W. Fenical, J. Nat. Prod., 2010, 73, 998-1001.

192 M. Isaka, P. Chinthanom, T. Boonruangprapa, N. Rungjindamai and U. Pinruan, J. Nat. Prod., 2010, 73, 683-687.

193 S. B. Singh, D. Zink, J. Polishook, D. Valentino, A. Shafiee, K. Silverman, P. Felock, A. Teran, D. Vilella, D. J. Hazuda and R. B. Lingham, Tetrahedron Lett., 1999, 40, 8775-8779.

194 I. E. Mohamed, H. Gross, A. Pontius, S. Kehraus, A. Krick, G. Kelter, A. Maier, H.-H. Fiebig and G. M. König, Org. Lett., 2009, 11, 5014-5017.

195 C. Hemtasin, S. Kanokmedhakul, K. Kanokmedhakul, C. Hahnvajanawong, K. Soytong, S. Prabpai and P. Kongsaeree, J. Nat. Prod., 2011, 74, 609-613.

196 K. Minagawa, S. Kouzuki, J. Yoshimoto, Y. Kawamura, H. Tani, T. Iwata, Y. Terui, H. Nakai, S. Yagi, N. Hattori, T. Fujiwara and T. Kamigauchi, J. Antibiot., 2002, 55, 155164.

197 H. Kaise, M. Shinohara, W. Miyazaki, T. Izawa, Y. Nakano, M. Sugawara, K. Sugiura and K. Sasaki, J. Chem. Soc., Chem. Commun., 1979, 726-727.

198 B. B. Jarvis, J. Salemme and A. Morais, Nat. Toxins, 1995, 3, 10-16.

199 X. Ma, L. Li, T. Zhu, M. Ba, G. Li, Q. Gu, Y. Guo and D. Li, J. Nat. Prod., 2013, 76, 2298-2306.

200 K. Sakai, K. Watanabe, K. Masuda, M. Tsuji, K. Hasumi and A. Endo, J. Antibiot., 1995, 48, 447-456.

201 R. Uchida, R. Imasato, Y. Yamaguchi, R. Masuma, K. Shiomi, H. Tomoda and S. Ōmura, J. Antibiot., 2005, 58, 397-404.

202 S. B. Singh, D. L. Zink, A. W. Dombrowski, G. Dezeny, G. F. Bills, J. P. Felix, R. S. Slaughter and M. A. Goetz, Org. Lett., 2001, 3, 247-250.

203 W. Wilk, H. Waldmann and M. Kaiser, Bioorg. Med. Chem., 2009, 17, 2304-2309. 